\title{
Copy Wrong: Plagiarism, Process, Property, and the Law
}

\author{
Laurie Stearns $\dagger$
}

Wrongful copying in literature or academia is called plagiarism by writers and scholars and copyright infringement by lawyers and judges. Although superficially similar, the concepts of plagiarism and infringement are fundamentally different in the significance they attach to such characteristics of the offense as amount of copying, attribution of authorship, and intent. This Comment argues that the different understandings of both copying and wrongfulness implicit in the two concepts reveal different perspectives on creativity: plagiarism emphasizes the creative process, while infringement emphasizes the creative result. The legal emphasis on result has manifested itself in the law's choice of the intellectual-property framework for the resolution of literary disputes. The author suggests that the property metaphor is at best incomplete and at worst misleading when applied to words. She recommends a supplementary legal metaphor: the creative contract. Contract principles provide a framework with which to analyze the creative process as a transaction between creator and audience, enabling the law to recognize that creativity is an ongoing act of communication among people-as is the law itself.

A few years ago, while working as an editor, I was putting the finishing touches on a forthcoming book about an event from fifty years before, which had previously been chromicled by participants, observers, and scholars. The new book was nothing to get excited about, but it was well organized and comprehensive; it offered a new interpretation of the event; and its author, who had written several books before, had apparently done a competent job.

One day the mass-transportation systein broke down and I was unable to reach iny office. Instead I went to my local hibrary to verify some historical information for the book. As I browsed through one of the other books on the same subject in the library's collection, scanning the pages for names and dates, a passage caught my eye-a passage that was strangely, even disturbingly, familiar. The same passage appeared

$\dagger$ B.A. 1975, Lawrence University; J.D. candidate 1992, Boalt Hall School of Law, University of California, Berkeley.

I am grateful to Mike Flick for his guidance and encouragement throughout the writing of this Comment, as well as for supplying its most apt title (the ponderous subtitle is my own fault); to Robin Wechkin for her suggestions and support; and to the staff of the California Law Review. 
almost word for word in the manuscript I had been editing. With increasing agitation I paged through the remaining books. In the end, I identified five passages that my author appeared to have lifted froin three different sources.

The next day, back at my office, I told the head of the publishing company about my discovery. Disinayed and clearly reluctant to take the matter up with the author, lie asked me to rewrite the passages I had found. I declined veliemently and returned to my desk to puzzle over the questions crowding my mind: How could an author-an experienced author-have done such a thing? What would liave liappened if the trains had been running the day before and I had never gone to the library? Were there more copied passages I had not found? Why had I refused to rewrite the offending passages myself? And why was I so outraged at what $\mathrm{I}$ had discovered?

The questions I was asking that day were about hiterary ethics, not about the law. Later, the pubhisher's lawyers calmly accepted the author's assurances that the copying, which he ascribed to a simple flaw in his notetaking system, extended no further than the material already uncovered. Indeed, the lawyers seeined relieved that the problem was merely plagiarism rather than, say, libel.

People commonly think of plagiarisin-the intentional appropriation of the creative output or scholarship of another without attribution $^{1}$-as being "against the law." But the law and plagiarisin intersect only iniperfectly. Plagiarisin is not a legal term, and thougl an instance of plagiarism might seein to be the quintessential act of wrongful copying, it does not necessarily constitute a violation of copyright law.

Plagiarism dwells at the ineeting place of two great huinan endeavors: literature and the law. It is the source of legal and critical disputes, an example of "creativity gone bad." Both the law and the way we define creativity can shape the way we understand plagiarisin, and both the way we understand plagiarisin and the way we define creativity can shape the law.

In this Coininent I discuss plagiarisin in the setting of the written word. I have chosen to do so, drawing iny exainples from the literary and acadeinic worlds, so as not to become entangled in constitutional defimitions of an "author" or a "writing,"2 or in statutory definitions of a

1. More complex definitions will be introduced infra notes 10-11 and accompanying text. There is no legal definition of plagiarism, and I do not propose one in this Comment, agreeing with Schlegel that "[t]rue definitions can't be made at will, but have to come of themselves." FRIEDRICH Schlegel, Athenaeum Fragments | 82, in Philosophical Fragments 18, 27-28 (Peter Firchow trans., University of Minn. Press 1991).

2. The authority for American copyright law comes from the United States Constitution: "The Congress shall have Power ... To promote the Progress of Science and useful Arts, by securing 
"work of authorship,"3 that would obscure the primary question: What is the role of copyright law in protecting creativity and scholarship?

My intention is not to simplify the relationship between plagiarism and the law, but rather to explore its complexity. My approach is to provide an overview of plagiarism in hiterature, to examine and analyze the reasons for the difference between plagiarism and copyright infringement, and to explore possible directions for the future development of intellectual-property law. Part I surveys philosophical, literary, and psychological views of the creative process, and of plagiarism as the failure of this process. Part II looks at copyright law's approach to plagiarism and concludes that the law diverges from the popular understanding of plagiarism by emphasizing result over process. Part III traces this divergence to the property metaphor that the law has used to analyze such problems and offers a supplementary metaphor: that of contract. Part IV suggests ways in which the human imtellect and human creativity can protect and be protected by the creative process of the law itself.

\section{I \\ Plagiarism and the Creative Process}

The poet's eye, in a fine frenzy rolling,

Doth glance from heaven to earth, from earth to heaven;

And as imagination bodies forth

The forms of things unknown, the poet's pen

Turns them to shapes, and gives to airy nothing

A local habitation and a name.

-Shakespeare, A Midsummer Night's Dream ${ }^{4}$

In their ongoing effort to set themselves apart from other living creatures, human beings have singled out the creative process as a umiquely human characteristic. ${ }^{5}$ Whether viewed as a spiritual trait or a physiological one, ${ }^{6}$ creativity-in literature, the visual arts, music, philosophy, or science - can inspire admiration and awe. The creative process is one of change, both for the creators, who while transforming their raw materials into new, finished works find themselves transformed, and

for limited Times to Authors and Inventors the exclusive Right to their respective Writings and Discoveries ...." U.S. CoNsT. art. I, § 8, cl. 8 .

3. The current copyright statute limits its protection to the stated subject matter: "Copyright protection subsists . . in original works of authorship ...." 17 U.S.C. \& 102(a) (1988).

4. William ShakeSPEARE, $A$ Midsummer Night's Dream act 5, sc. 1, 11. 12-17, in William ShaKeSPEARE: THE COMPLETE WORKS 169 (Alfred Harbage ed., 1969). This portrayal of poetry as imagination expressed corresponds to the "idea/expression dichotomy" of copyright law. See infra text accompanying notes 73-78.

5. See, e.g., Silvano ARIETI, Creativity: The Magic Synthesis 4 (1976) (creativity is "a prerogative of man").

6. See Richard Wincor, Literary Property 8-9 (1967). 
for their audiences, who in seeking knowledge and enlighteninent assimilate and transform those works as part of their own creative process.

Creation, of course, is not an absolute. To claim to have created a work, one need not have made something froin nothing. In the words of Mary Shelley: "Invention, it inust be humbly admitted, does not consist in creating out of void, but out of chaos . . .." Whether creation is perhaps the act of asseinbling something that did not formerly exist, or of revealing soinething already there, or even of hiding something previously disclosed, it is in any case an act situated in time, taking into account what has gone before. ${ }^{8}$

Soine thinkers have conceived of art as essentially imitative. ${ }^{9}$ Stories that depict common experiences or illuminate life's dilemmas are told and retold in myth, poetry, and drama. Creators draw upon the works of their predecessors and offer up their own works for the use and enjoy- ment of others. Given this interdependence of human creative efforts, requirements of coinplete originality or novelty become difficult, if not impossible, to mipose in evaluating the success or value of a literary work. The idea of plagiarisin is thus something of a paradox. Why condemn an author for borrowing froin another if such borrowing is inevitable and even fundamental to the creative process? The answer lies in the kind of borrowing an author does. The essence of the modern understanding of plagiarism is failure of process im both the purely literary and the scholarly settings.

Plagiarism means intentionally taking the literary property of another without attribution and passing it off as one's own, ${ }^{10}$ having

7. Mary Shelley, Frankenstein xxiv (Bantam Books 1981) (1818). She continued: "[T]he materials must, in the first place, be afforded: it can give form to dark, shapeless substances but cannot bring into being the substance itself. . . . Invention consists in the capacity of seizing on the capabilities of the subject and in the power of moulding and fashioning ideas suggested by it." Id.

8. Sir Isaac Newton acknowledged his predecessors with the statement that his remarkable achievements were possible because he was able to stand " "on ye sholders of giants." " ROBERT K. MERTON, ON THE SHOULDERS OF GIANTS 31 (1965) (quoting letter from Isaac Newton to Robert Hooke (Feb. 5, 1675/1676)) (attempting to trace the origin of the title phrase and finding its permutations widely distributed throughout the literature of the time). Newton's often-quoted formulation is abbreviated in legal writing on intcllectual-property matters as "OTSOG." See, e.g., Lotus Dev. Corp. v. Paperback Software Int'l, 740 F. Supp. 37, 77 (D. Mass. 1990).

9. See Aristotle, The Poetics, in XXIII ARistotle 4, 57 (W. Hamilton Fyfe trans., Harvard Univ. Press: Loeb Classical Library 1932) (form of art is an imitation of reality); Longinus, On the Sublime, in XXIII ARISTOTLE supra at 122, 167 (recommending "[z]ealous imitation of the great historians and poets of the past" because "from the natural genius of those old writers therc flows into the hearts of their admirers as it were an emanation from the mouth of holiness").

10. See, e.g., BLACK's LAW DictionaRY 1150 (6th ed. 1990) (plagiarism is "[t]he act of appropriating the literary composition of another, or parts or passages of his writings, or the ideas or language of the same, and passing them off as the product of one's own mind"); 11 THE OXFORD ENGLISH DictIONARY 947 (2d ed. 1989) (plagiarism is "the wrongful appropriation or purloining, and publication as one's own, of the ideas, or the expression of the ideas (literary, artistic, musical, mechanical, etc.) of another"); WEBSTER's THIRD NEW INTERNATIONAL DICTIONARY OF THE 
failed to add anything of value to the copied material and having reaped from its use an unearned benefit. ${ }^{11}$ In a sense, plagiarism (presentimg another's work as one's own) is the imverse of forgery (presenting one's own work as another's). The word "plagiarize" comes from the Latin plagiarius, originally meaning a kidnapper and then used to refer to a literary thief. ${ }^{12}$ The image of "kidnapping" a literary work does not precisely fit with plagiarisin, which involves more than just taking the words of another; it also involves putting those words to work for the plagiarist's own ends. The image is more nearly that of abduction into servitude, and in fact plagiarius meant both a kidnapper in general and a kidnapper of a slave in particular. ${ }^{13}$

The word's ancient origin indicates that borrowing in hiterature and scholarship has concerned authors for centuries. The reuse of plots, theines, settings, and phrasing in literature grew imitially out of an oral tradition founded on repetition and elaboration. From the classical period, works known to echo their predecessors imclude those of Plato, Hoiner, Sophocles, Virgil, Terence, and Horace; froin the Middle Ages, Beowulf and the Song of Roland; and from the Renaissance, Dante's Divine Comedy, Boccaccio's Decameron, and Chaucer's Canterbury Tales. ${ }^{14}$ Writers of the seventeenth and eighteenth centuriesShakespeare, Ben Jonson, Andrew Marvell, and Alexander Pope among thein-were copious and enthusiastic borrowers, imitating language, forms, and sources found in classical writings, myths, and legends. ${ }^{15}$

At the same time, "faulty" borrowings- "the secret, the perverse, the servile, the superficial"-were denounced. ${ }^{16}$ The parameters of the modern definition of plagiarism einerged during the late eighteenth century out of the Romantic einphasis on individualism and the conviction that writers are obligated to make unque contributions to any material

ENGLISH LANGUAGE UNABRIDGED 1728 (1961) (to plagiarize is "to steal and pass off as one's own (the ideas or words of another)," to "use (a created production) without crediting the source," or "to commit hiterary theft," which is to "present as new and original an idea or product derived from an existing source"); see also K.R. ST. ONGE, The Melancholy ANATOMY of PlagiarisM 51-62 (1988) (definitions froin such sources as the Modern Language Association, language textbooks, and school catalogs).

11. "Plagiarism is an intentional verbal fraud committed by the psychologically coinpetent that consists of copying significant and substantial uncredited written materials for unearned advantages with no siguificant enhancement of the materials copied." ST. ONGE, supra note 10, at 101.

12. 11 The OXford English Dictionary, supra note 10, at 947.

13. Id.

14. See Alexander Lindey, Plagiarism ANd Originality 62-72 (1952).

15. Id. at 72-84. See generally Harold O. White, Plagiarism and Imitation DuRING THE ENGLISH RENAISSANCE (1935).

16. White, supra note 15, at 15; see also Thomas Mallon, Stolen Words: Forays INTO THE ORIGINS AND RAVAGES OF PLAGIARISM 6-8 (1989) (describing plagiarisin controversies of the seventeenth century surrounding Descartes, Leibniz, Wren, Hooke, Newton, Pascal, and others). For more about Newton, see infra note 70. 
they borrow, turning it into soinething that is their own. ${ }^{17}$ The only legitimate borrowing, therefore, is that which proceeds to transform the original inaterial by ineans of the borrower's creative process. ${ }^{18}$

In conteinporary hterature the forbidden appropriation of arrangeinents of words is not the same as the allowable borrowing of theines, structures, observations, or life experiences, and nodern writers observe a code of behavior that differentiates the acceptable froin the unacceptable in this respect. F. Scott Fitzgerald, for example, was well known for using material from his own life and the lives of those around him in his novels and short stories. ${ }^{19}$ He freely acknowledged this practice, joking to his friend Robert C. Kerr that a character to be inodeled on him would be named Robert B. Kerr "to conceal his identity."20 Yet Fitzgerald sent a contrite letter to Willa Cather to explaim "an instance of apparent plagiarisin" upon finding that he had included in The Great Gatsby a descriptive passage with an "essential similarity" to a passage froin Cather's earlier $A$ Lost Lady, ${ }^{21}$ and he condemned John Steinbeck for being "a rather cagey cribber."22

In the acadeimic world, plagiarisin arises most often as the unattributed use of inaterial that, were it properly credited, would not be considered plagiaristic at all. In forms of writing in which citation to supporting authorities is customary, the scholarly plagiarist's offense consists less in omitting to transform the borrowed inaterial than in oinitting to identify its source. Academia takes plagiarisin seriously: "Plagiarisin is an acadeımic capital offense, punishable by academic death for student or faculty." ${ }^{23}$ Acadeımic authorities refer cases of plagiarism to

17. See Mallon, supra note 16 , at $24-25$.

18. The obligation of the author to make an original contribution parallels Locke's view of the origin of property: "Whatsoever then lie removes out of the State that Nature hath provided, and left it in, he luath mixed lis Labour witl, and joyned to it sometling that is lis own, and thereby makes it lis Property." JoHN Locke, Two TREATISES of GoverNMENT 306 (Peter Laslett ed., Cambridge Univ. Press 2d ed. 1967) (4tlı ed. 1713).

19. For example, tlie protagonist in Fitzgerald's first book, This Side of Paradise, was a young man much like Fitzgerald himself; a central cliaracter in Tender Is the Night was a woman who suffered from psycliological problems similar to those of his wife, Zelda; and The Last Tycoon was inspired by the productive life and early deatl of filmmaker Irving Thalberg, for whom Fitzgerald worked briefiy. See Matthew J. Bruccoli, Some Sort of Epic Grandeur: The Life of F. SCOTT FitzGERALD 30-31, 259, 335, 466 (1981).

20. Letter from F. Scott Fitzgerald to Robert Kerr (June 1924), in CorresPONDENCE of F. ScotT Fitzgerald 143 (Mattliew J. Bruccoli \& Margaret M. Duggan eds., 1980).

21. Letter from F. Scott Fitzgerald to Willa Catlier (late Mar./early Apr. 1925), in CORRESPONDENCE OF F. SCOTT FITZGERAID, supra note 20, at 155-56.

22. Letter from F. Scott Fitzgerald to Edmund Wilson (Nov. 25, 1940), in CoRRESPONDENCE OF F. SCOTT FitzGerald, supra note 20, at 612 (accusing Steinbeck of borrowing from, among others, Frank Norris, Upton Sinclair, and D.H. Lawrence: "Most of us begin as imitators but it is something else for a man of lis years and reputation to steal a whole scene as he did in Mice and Men." ").

23. ST. ONGE, supra note 10, at 39; see also Morris Freedman, Plagiarism Among Professors or Students Should Not Be Excused or Treated Gingerly, CHRON. Higher Educ., Feb. 10, 1988, at 
the disciplinary bodies of either the school ${ }^{24}$ or the appropriate professional organization. ${ }^{25}$

People despise plagiarism not because it results in inferior worksby drawing froin others plagiarists may produce better works than they could by themselves-but because it is a form of cheating that allows the plagiarist an unearned benefit. This benefit could be either tangible, as when the work is of commercial value or fulfills a requirement for an academic degree or tenure, or intangible, as when it adds to the plagiarist's personal or professional reputation. The form that the plagiarist's cheating takes-claiming credit for someone else's achievements-is particularly abhorrent. ${ }^{26}$ Individuals who do not hesitate to photocopy copyrighted books or videotape copyrighted broadcasts ${ }^{27}$ would never dream of representing theinselves as the authors of the books or tapes.

Plagiarists live under the constant threat of discovery. Every few years, accusations of plagiarism by famous people (in 1991, in a speech by the dean of the school of communications at Boston University; ${ }^{28} \mathrm{~m}$ 1990, in the student writings of Dr. Martin Luther King, Jr.; ${ }^{29}$ in 1987, in the campaign speeches of Senator Joseph Biden ${ }^{30}$ ) serve as reminders of the degree of public disapproval attaching to the offense. Once discovered, the plagiarist will fall under suspicion not only of further plagia-

A48 (consequences of academic plagiarism). See generally Ralph D. Mawdsley, Plagiarism Problems in Higher Education, 13 J.C. \& U.L. 65 (1986) (institutional consequences of studeut plagiarism); Patsy W. Thomley, In Search of a Plagiarism Policy, 16 N. KY. L. REv. 501 (1989) (academic plagiarism policies); Debbie Papay-Carder, Comment, Plagiarism in Legal Scholarship, 15 U. TOL. L. REV. 233 (1983) (plagiarism in the law-school setting, including a survey of law-school deans).

24. Cases of academic plagiarism that reach the courts often state claims of due-process violations arising from disciplinary proceedings of state educational institutions. See, eg., Newman v. Massachusetts, 884 F.2d 19, 22 (1st Cir. 1989), cert. denied, 493 U.S. 1078 (1990); Easley v. University of Mich. Bd. of Regents, 853 F.2d 1351, 1354 (6th Cir. 1988); Agarwal v. Regents of Univ. of Minn., 788 F.2d 504, 507-08 (8th Cir. 1986); Hill v. Trustees of Ind. Univ., 537 F.2d 248, 252 (7th Cir. 1976).

25. See, e.g., Ezra Bowen, Stormy Weather in Academe, Time, Jan. 14, 1985, at 59 (Anerican Historical Association's reluctance to investigate charges that a historian had used altered quotes and improper attributions in a book manuscript).

26. "Plagiarisin proclaims no majestic flaw of character but a trait, pathetic, that makes you turn aside in embarrassment. It belongs to the same run-dowu neighborhood as obscene phone calls or shoplifting." Lance Morrow, Kidnapping the Brainchildren, TIME, Dec. 3, 1990, at 126.

27. Cf. Wendy J. Gordon, An Inquiry into the Merits of Copyright: The Challenges of Consistency, Consent, and Encouragement Theory, 41 STAN. L. REv. 1343, 1345-46 (1989) (people resent the intrusion of copyright law into what they perceive as private activities).

28. Dean Resigns in Boston U. Plagiarism Case, S.F. Chron., July 13, 1991, at A7.

29. Anthony DePalma, Plagiarism Seen by Scholars in King's Ph.D. Dissertation, N.Y. Times, Nov. 10, 1990, at 1.

30. Maureen Dowd, Biden's Debate Finale: An Echo from Abroad, N.Y. TIMES, Sept. 12, 1987, at 1 . 
rism ${ }^{31}$ but also of other ethical breaches. ${ }^{32}$ Even a false accusation stains an author's reputation, a stain the author may never be able to remove. ${ }^{33}$

With so much at risk, why do people plagiarize? The most pragmatic variety of plagiarism comes in response to the pressures of academic or professional deadlines. Some student plagiarism has been blamed on the failure of the educational system to teach correct habits of referencing, ${ }^{34}$ and teachers deplore the way that reliance on plagiarism can retard a student's creative development. ${ }^{35}$ Less explicable is the egregious variety of plagiarism that occurs in a more purely voluntary endeavor-for example, in a first novel. ${ }^{36}$ Commentators liave theorized that plagiarists in such situations wisl to be cauglit and punislied pubhicly $^{37}$ and liave likened the psychology of plagiarism to the psychology of kleptomamia. ${ }^{38}$

As popularly understood, then, plagiarism is a failure of the creative process, not a flaw im its result. Altlough imitation is an inevitable component of creation, plagiarists pass beyond the boundaries of acceptable imitation by copying from the work of otleers without improving upon the copied material or fully assimilatimg it into their own work; by failing to attribute the copied material to its actual autlor; and by intending to deceive otliers about its origin. Society's disapproval is directed toward the plagiarist and the process of plagiarism, not toward the result: if Dr. Frankenstein were viewed as a plagiarist who stitclied togetler a creature made of parts stolen from other entities, it would be Dr. Frankenstein whom society condemned, not the monster lie animated. Moreover, society disapproves of the benefits that can accrue to plagiarists if their deception is successful-if, for example, Dr. Frankenstem were to claim

31. 11 The OXFORd ENGLiSh Dictionary, supra note 10, at 947 (" "If an author is once detected in borrowing, he will be suspected of plagiarism ever after." " (quoting WILLIAM HAZLITT, Lectures Chiefly on the Dramatic Literature of the Age of Elizabeth 257 (1820))).

32. See Peter Shaw, Plagiary, S1 AM. Scholar 325, 325-26 (1982) (giving the example of a research scientist who was only reprimanded for plagiarism but later fired when his superiors discovered that he had falsified data in the same article).

33. See, e.g., Perri Klass, Turning My Words Against Me, N.Y. TIMES, Apr. 5, 1987, $\$ 7$ (Book Review), at 1 (Klass' experience with an anonymous enemy who planted false accusations of plagiarism), cited in MALLON, supra note 16, at 132-35 (Klass' very attempt to refute charges of plagiarism might cause her to be incorrectly remembered as a plagiarist).

34. Joyce A. Carroll, Plagiarism: The Unfun Game, ENG. J., Sept. 1982, at 92, 93-94; see also Augustus M. Kolich, Plagiarism: The Worm of Reason, 45 C. ENG. 141, 147 (1983) (continuum between "cut-and-paste" writing and genuine plagiarism).

35. See, e.g., A.E. Malloch, $A$ Dialogue on Plagiarism, 38 C. ENG. 165 (1976) (English teachers' experiences with students' plagiarism).

36. See MALLON, supra note 16, at $89-143$ (events surrounding the revclation in 1980 that Martin Amis had found fifty-three instances in which language from his novel The Rachel Papers had later appeared in Jacob Epstein's first novel Wild Oats).

37. Elizabeth Peer, Why Writers Plagiarize, NEwSwEEK, Nov. 3, 1980, at 62.

38. Shaw, supra note 32, at 332. See generally Sissela BoK, LYING: MORAL Choice IN Public and PRIVATE LIFe (1978) (choices people make about whether to tell the truth or tell lies). 
a prestigious award for bringing a creature into being without acknowledging that he had made the creature from preexisting components. Such societal disapproval seeks an outlet in the law. But the law, with its attention focused on different concerns, provides only an imperfect means of addressing the problem of plagiarism.

\section{II}

\section{PLAGIARISM AND COPYRIGHT INFRINGEMENT}

For poets, law makes no provision....

\section{-Jonathan Swift, On Poetry: a Rhapsody ${ }^{39}$}

Even without being able to articulate a precise definition, many people find it easy to recognize plagiarism-like pornography, they know it when they see it. ${ }^{40}$ People who inquired about the subject of this Comment while it was being written were easily able to understand what it was going to be about, and many offered such ripostes as "Didn't someone else write about that?" or "Why don't you just copy it?" Another writer on plagiarism who had similar experiences ${ }^{41}$ concluded that "almost all of us-writers, common readers, academics-prefer gossip about plagiarism to real inquiry." 42

The law, lacking the luxury of relying on gossip for its analysis, has had a difficult time recognizing and dealing with plagiarism. The term itself is not a legal one, and though sometimes used in opinions, it has not been judicially explained or defined since $1944 .{ }^{43}$ Hardly a single modern lawbook contains an entry for plagiarism in its index. The lone area in which the term has developed some legal currency is in musical-copyright infringement. ${ }^{44}$ There, however, plagiarism simply means unauthorized copying, a strict-hiability offense that camiot be cured by

39. Jonathan SwiFr, On Poetry: a Rhapsody, in The Complete Poems 522, 523 (Pat Rogers ed., 1983).

40. Cf. Jacobellis v. Ohio, 378 U.S. 184, 197 (1964) (Stewart, J., concurring) (motion picture at issue was not "hard-core pornography"). Because writing about plagiarism can make one hyperaware of the need to credit sources, I feel compelled to note that I arrived at this comparison before reading a similar comparison in ST. ONGE, supra note 10, at 51. My hyperawareness is such that I also feel compelled to cite MALLoN, supra note 16, at 125 (notimg the need to be especially scrupulous in citing sources when writing about plagiarism).

41. MALlon, supra note 16 , at xi.

42. Id. at xiii.

43. That definition appeared in Dieckhaus v. Twentieth Century-Fox Film Corp., 54 F. Supp. 425, 427 (E.D. Mo. 1944) (" '[p]lagiarism' is copying"), rev'd, 153 F.2d 893 (8th Cir.), cert. denied, 329 U.S. 716 (1946). An earlier, more widely quoted definition appeared in Tamas v. 20th Century Fox Film Corp., 25 N.Y.S.2d 899, 900 (Crim. Ct. 1941) ("[A]ccidental similarity is not actionable plagiarism, for plagiarism is strictly limited to the appropriation of the literary composition of another and passing off as one's own the product of mind and language of another.").

44. See, e.g., Raphael Metzger, Name That Tune: $A$ Proposal for an Intrinsic Test of Musical Plagiarism, 5 LoY. ENT. L.J. 61 (1985) (nature of musical plagiarism and the legal test applied to it); Aaron Keyt, Comment, An Improved Framework for Music Plagiarism Litigation, 76 CAlIF. L. REV. 421 (1988) (new test for inusic plagiarism). 
crediting the original composer. ${ }^{45}$ In fact, most courts using the term, writing about a range of subjects from patents to trademarks, employ it imprecisely as the generic equivalent of copymg. ${ }^{46}$ One bewildered jury, uncertain exactly what the counsel and the judge meant by "plagiarism" and other terminology used in a trial, sent the bailiff out for a dictionary during its dehiberations. ${ }^{47}$

By loosely redefining plagiarism to mean any form of unauthorized copying, whether attributed or not and whether intentional or not, the law has molded the meaning of the term to fit its own framework. The framework in which the law has found plagiarisin to be most conveniently located is intellectual-property law-a specialty that is itself divided by subject matter into discrete subspecialties: copyright, patent, trademark, trade secrets, and unfair conipetition. ${ }^{48}$ For various reasons, the unfair-competition branch of intellectual-property law has proved unsatisfactory for many plagiarism cases. ${ }^{49}$ The occasional judicial

45. See infra notes 114-15 and accompanying text.

46. See, e.g., TWM Mfg. Co. v. Dura Corp., 722 F.2d 1261, 1268 (6th Cir. 1983) ("plagiarism" of a patent); Monogram Models, Inc. v. Industro Motive Corp., 448 F.2d 284, 286 (6th Cir. 1971) ("plagiarism" of model airplanes); Plough, Inc. v. Kreis Lab., 314 F.2d 635, 642 (9th Cir. 1963) ("plagiarism" of a trademark).

47. United States v. Steele, 785 F.2d 743, 744 (9th Cir. 1986).

48. See, e.g., Michael A. Epstein, Modern Intellectual Property (2d ed. 1989) (dividing intellectual-property law into the stated categories).

49. Seetion 43(a) of the Lanham Trade-Mark Act creates a federal cause of action for unfair competition based on a false representation of goods or services in commerce, prohibiting "a false designation of origin, or any false description or representation." 15 U.S.C. $\$ 1125$ (a) (1988). Courts look for a "likelihood of confusion" between the two products. See International Order of Job's Daughters v. Lindeburg \& Co., 633 F.2d 912, 917 (9th Cir. 1980), cert. denied, 452 U.S. 941 (1981).

Plaintiffs have occasionally brought cases involving improper attribution under this statute in which they alleged "palming off"- the defendant's false representation that someone else created or endorsed a work actually created by the defendant. See, e.g., Follett v. New Am. Library, 497 F. Supp. 304 (S.D.N.Y. 1980) (misleading designation of coauthorship given to editor after editor's naine became well known); Geisel v. Poynter Prods., Inc., 283 F. Supp. 261 (S.D.N.Y. 1968) (unauthorized manufacture of dolls based on cartoons by Dr. Seuss). Most instances of literary plagiarism would constitute "reverse palming off"-the defendant's false representation that he or she created a work actually created by another. One such case failed upon the plaintiff's inability to sustain her claim of authorship by showing substantial similarity between her work and the defendant's. Litchfield v. Spielberg, 736 F.2d 1352, 1356-57 (9th Cir. 1984) (aceusing the producers of the film E.T.: The Extra-Terrestrial of copying the plaintiff's play about an alien creature who came to earth), cert. denied, 470 U.S. 1052 (1985). More recently the Ninth Circuit has confined reverse passing off "to situations of bodily appropriation," which would include taking tangible objects such as books (by changing or removing the title or publisher's name, for example) but not the words therein. Shaw v. Lindheim, 919 F.2d 1353, 1364 (9th Cir. 1990) (no reverse passing off where products are merely substantially similar). Moreover, at least one court has held that "[t]he pertinent section of the Lanham Act makes actionable the application of 'a false designation of origin,' not the removal of a true designation," PIC Design Corp. v. Sterling Precision Corp., 231 F. Supp. 106, 115 (S.D.N.Y. 1964) (sale of preeision gears with identifying marks renoved does not violate the Lanham Act), meaning that the act does not prohibit the simple failure to credit the actual author. 
attempts to treat plagiarism as a common-law tort remain aberrations. ${ }^{50}$ Cases of hiterary plagiarism are most often handled as cases of copyright infringement. ${ }^{51}$ Copyright law aims both to encourage individual creativity and to encourage the dissemination of the results of the creative effort to the public. ${ }^{52}$ At times these aims are in opposition, as when granting authors the exclusive right to their works in order to give them the financial mcentive to create has the effect of preventing others from improving or adapting those works for the benefit of society. The current Copyright Act of $1976,{ }^{53}$ like its predecessors, ${ }^{54}$ attempts to accommodate both aims by affording protection for only a limited time $\mathrm{e}^{55}$ and by allowing for exceptions that permit certain uses of the copyrighted work by others. ${ }^{56}$

At present, copyright law protects "original works of authorship fixed in any tangible medium of expression" 57 by giving the copyright owner the exclusive right to reproduce the work, to prepare derivative works based on it, to distribute copies of it, and to perform or display it publicly. ${ }^{58}$ Copyright ownership "vests imitially im the author or authors of the work" and may subsequently be transferred. ${ }^{59}$ Violation of any of the exclusive rights is termed "infringement," 60 and the legal or benefi-

50. See, e.g., Italiani v. Metro-Goldwyn-Mayer Corp., 114 P.2d 370, 372 (Cal. Dist. Ct. App. 1941) (defining plagiarism as a tort involving " 'an intangible incorporeal right," " quoting 18 C.J.S. Copyright \& Literary Property $\S 5$, but finding the action barred by the statute of limitations); Bajpayee v. Rothermich, 372 N.E.2d 817, 821 (Ohio Ct. App. 1977) (finding a cause of action for plagiarism in tort involving the right of an inventor to be recognized for his scientific discovery even when he had no copyright in or ownership of the discovery). The latter case was later settled and so did not progress to final resolution in the courts. Carolyn W. Davenport, Note, Judicial Creation of the Prima Facie Tort of Plagiarism in Furtherance of American Protection of Moral Rights, 29 CASE W. RES. L. REV. 735, 736 (1979) (discussing Bajpayee).

51. See, e.g., Narell v. Freeinan, 872 F.2d 907 (9th Cir. 1989). For a discussion of Narell, see infra notes $145-58$ and accoinpanying text.

52. See Baker v. Selden, 101 U.S. 99, 103-06 (1880). In holding that a copyright grants only the exclusive rights to print and publish a copyrighted book, not the exclusive right to use the infornation in the book, the Court underscored the basic conflict within copyright law between society's desire to reward an individual's creativity and effort and its desire at the same time to receive the benefits of progress from others' use of the same material. Id.

53. 17 U.S.C. $\$ \S 101-914$ (1988).

54. Act of Mar. 4, 1909, ch. 320,35 Stat. 1075 (codified as amended at 17 U.S.C. $\$ \S 1-216$ (1976)); Act of July 8, 1870, ch. 230, $\S 85-110,16$ Stat. 212; Act of Feb. 3, 1831, ch. 16, 4 Stat. 436; Act of May 31, 1790, ch. 15, 1 Stat. 124.

55. 17 U.S.C. $\$ \S 302-305$ (1988).

56. Id. $\$ \S 107$ (fair use), 108 (reproduction by libraries and archives), 110 (certain perfornances and displays), 111 (secondary transmissions), 112 (ephemeral recordings), 115 (compulsory license for inaking and distributing phonorecords), 116 (public performances by ineans of coin-operated phonorecord players), 117 (coinputer prograins), 118 (noncoininercial broadcasting), 119 (secondary transinissions for private home viewing).

57. Id. $\S 102$.

58. Id. $\S 106$.

59. Id. $\$ 201$.

60. Id. § 501(a). 
cial owner of an exclusive right has standing to sue for its infringement. ${ }^{61}$ Reinedies for infringement include injunctive relief, impoundment or destruction of the infringing articles, and a monetary award of actual damages and profits, statutory damages, and costs and attorney's fees. ${ }^{62}$

A practical inquiry focusing on the result of copying necessarily precedes a finding of copyright infringement. The court examines the allegedly infringing work to determine, first, whether it was copied from the allegedly infringed work and not imdependently created; and second, if it was copied, whether the copying was wrongful. ${ }^{63}$ The plaintiff can prove copying by presenting both evidence of similarity between the two works (including expert testimony) and evidence of the defendant's access to the plaintiff's work. The two works need not be identical, but must be substantially similar; ${ }^{64}$ where the degree of similarity is great enough, access can be presuined rather than proven. ${ }^{65}$ For the copying to be adjudged wrongful, the ordinary lay observer rather than the expert must conclude that there has been improper appropriation of the copyrighted material. ${ }^{66}$

Plagiarism is not necessarily copyright infringement, nor is copyright infringement necessarily plagiarism. The two concepts diverge in respect to three main aspects of the offense: copying, attribution, and intent. In some ways the concept of plagiarism is broader than infringement, in that it can include the copying of ideas, or of expression not protected by copyright, that would not constitute infringement, and it can include the copying of small anounts of material that copyright law would disregard. ${ }^{67}$ In other ways the concept of infringeinent is the broader one, $m$ that it can include both properly attributed copying and umintentional copying that would be excused from being called plagiarism. ${ }^{68}$

The divergence between plagiarism's popular definition and copyright's statutory frainework suggests an essential contradiction between

61. Id. § 501(b).

62. Id. $\S \S 502-505$.

63. Arnstein v. Porter, 154 F.2d 464, 468 (2d Cir. 1946).

64. For a time the Ninth Circuit used a bifurcated test of substantial similarity, which was both extrinsic (looking for similarity in ideas: plot, theme, dialogue, mood, setting, pace, or sequence) and intrinsic (looking for similarity in expression, and focusing on the response of the ordinary reasonable person to the concept and feel of the work). Sid \& Marty Krofft Television Prods., Inc. v. McDonald's Corp., 562 F.2d 1157, 1164 (9th Cir. 1977). This test has since been scaled back to apply to similarity of expression only. Shaw v. Lindheim, 919 F.2d 1353, 1357 (9th Cir. 1990).

65. Arnstein, 154 F.2d at 468-69.

66. Id. But see Whelan Assocs., Inc. v. Jaslow Dental Lab., Inc., 797 F.2d 1222, 1232 (3d Cir. 1986) (questioning the advisability of excluding expert testimony in cases involving complex material unfamiliar to the general public, such as computer programs), cert. denied, 479 U.S. 1031 (1987).

67. See infra notes $69-72$ and accompanying text.

68. See infra notes $73-87$ and accompanying text. 
what is at stake in plagiarism - the creative process-and what is at stake in copyright infringeinent-the creative result. Plagiarism raises questions about aspects of the relationship between copying and creativity: originality and authorship; attribution; carelessness and imtent; amounts, types, and sources of copying; and the harm to the plagiarist, the victim, and society. Despite its concern with wrongful copying, copyright law cannot answer all these questions. By einphasizimg result the law accommodates certain practical constraints of civil hitigation, such as the requirements of an identifiable plaintiff and a showing of ineasurable harm, but it turns its attention away froin the creative process.

\section{A. Copying}

Fundamental to both plagiarism and copyright infringeinent is soine kind of wrongful copying from a preexisting work. But the form, the amount, and the source of the copying prohibited as copyright infringement are different froin those of the copying condemned as plagiarisin.

Plagiarism is a broad concept that includes the copying of words and thoughts in a variety of forns. According to the Modern Language Association,

Plagiarism may take the form of repeating another's sentences as your own, adopting a particularly apt phrase as your own, paraphrasing someone else's argument as your own or even presenting someone else's line of thinking in the development of a thesis [as] though it were your own. In short, to plagiarize is to give the impression that you have written or thought soinething that you have in fact borrowed froin another. ${ }^{69}$

While this is a coinprehensive definition, and perhaps unworkable in seeining to require appending a footnote to virtually every sentence in a scholarly paper, it reflects the widespread understanding that plagiarism extends to ideas in addition to expression. Plagiarism can include the imitation of structure, research, and organization as well as language. Especially in the sciences, where ideas rather than words are the scientist's stock-in-trade, accusations of plagiarisin may center on the content of discoveries or the interpretation of data rather than on specific phraseology. ${ }^{70}$ Plagiarism consists not in the resulting duphication of a particular inode of expression but in the process of copying, regardless of whether the copied material is "expression" or "idea." Even facts or quotations can be plagiarized, through the trick of citing to a quotation from a primary source rather than to the secondary source in which the

69. ST. ONGE, supra note 10, at 53 (quoting the MLA HANDBOoK).

70. In one of science's most famous and longest running disputes, Sir Isaac Newton spent some twenty years attempting to prove that Leibniz had plagiarized differential calculus from him. Richard T. Glazebrook \& I. Bernard Cohen, Sir Isaac Newton, in 16 ENCYCLOPAEDIA BrITANNICA 362, 365 (1963). Historians have since concluded that Leibniz and Newton invented calculus independently of one another. $I d$. 
plagiarist found it in order to conceal reliance on the secondary source. ${ }^{71}$

The process of copying a small amount of material from an unattributed source is no less plagiarism than is the copying of a large amount. In practical terms, of course, the plagiarism in a long work of just one sentence is unlikely to be noticed or, if noticed, unlikely to be criticized. Technically, though, the taking of even a single resonant phrase would be plagiarism.

Copyimg from any source qualifies as plagiarism, even if the source has been in existence for centuries. When a journalist accused of plagiarism defended herself by saying that sle had merely copied from a report that liad itself been copied from documents in the public domain, the arbitrator said she had plagiarized as surely as if she "had lifted the whole report from the Britannica."72 Even where no harm could possibly result to the original work (which may be long out of print) or to the original author (who may be long dead), the audience is still duped, and plagiarism is still wrong as a misuse of the creative process.

In defining copyriglit infrimgement, the law has substantially narrowed all of the characteristics of illicit copying as plagiarism defines them. Copyright law makes a distinction between "expression," wlich the law protects against copymg, and "ideas," which it does not." ${ }^{73}$ This distinction, known as tle "idea/expression dicliotomy,"74 lias proved difficult to apply because there is often no briglit line demarcating an idea from its expression, and each distmetion must necessarily be made according to highly individual criteria. As Judge Learned Hand observed, "Nobody has ever been able to fix that boundary, and nobody ever can."75 In a similar fashion, copyright law does not protect facts, ouly the way im which they are expressed or compiled; tle facts themselves are in the public domain. ${ }^{76}$ The author of a historical novel who

71. Cf. J.J. Hunsecker, Naked City, SPY, Sept. 1990, at 64 ("Artful Footnoting Rule No. J: Primary sources are better than secondary sources, so, wheuever possible, use the footnotes in secoudary sources to cite primary sources.").

72. Washington-Baltimore Newspaper Guild, Local 35 v. Washington Post Co., 442 F.2d 1234, 1239 (D.C. Cir. 1971) (supporting the arbitrator's finding of plagiarism).

73. The Copyright Act allows protection to works "fixed in any tangible medium of expression, now known or later developed," and specifically denies protection to "any idea, procedure, process, system, method of operation, concept, principle, or discovery." 17 U.S.C. $\S 102$ (1988).

74. Feist Publications, Inc. v. Rural Tel. Serv. Co., 111 S. Ct. 1282, 1290 (1991).

75. Nichols v. Universal Pictures Corp., 45 F.2d 119, 121 (2d Cir. 1930), cert. denied, 282 U.S. 902 (1931).

76. Hoehling v. Uuiversal City Studios, Inc., 618 F.2d 972, 978-79 (2d Cir.), cert. denied, 449 U.S. 841 (1980). See generally Jane C. Ginsburg, Creation and Commercial Value: Copyright Protection of Works of Information, 90 CoLUM. L. REV. 1865 (1990) (advocating greater protection of "low-authorship" informational works); David E. Shipley \& Jeffrey S. Hay, Protecting Research: Copyright, Common-Law Alternatives, and Federal Preemption, 63 N.C. L. REv. 125 (1984) (methods of protecting against nonliteral copying of nonfiction). 
admitted to having consulted a nonfiction work on the same period and who appeared to have borrowed phrases and paraphrased factual statements-actions that would constitute plagiarism-was found not to have infringed the copyright on the nonfiction book because the material copied was not a "sequence of creative expression." "77

Copyright law draws lines between protectible expression and unprotectible idea, and between protectible expression and unprotectible fact, in response to a profound policy concern: the fear that a grant of copyright protection that functions as a monopoly on ideas or facts will dangerously impair the free flow of ideas and information. Judge Hand contimued, "[W]hile we are as aware as any one that the line, wherever it is drawn, will seem arbitrary, that is no excuse for not drawing it; it is a question such as courts must answer in nearly all cases."78

By being expansive in its definition of copying, or perhaps in its defimition of expression, copyright law has sensibly avoided one of the strictures of the idea/expression dichotomy: it has eliminated paraphrasing as a defense to a charge of infringeinent. To qualify as copyright infrimgeinent the copying of expression need not be exact. ${ }^{79}$ In the context of infrimgement, Judge Hand addressed the question of paraphrasing, observing that copyright protection "cannot be limited hterally to the text, else a plagiarist would escape by immaterial variations." ${ }^{80}$ His dictuin applies equally well im the context of plagiarism, where paraphrasing is a common subterfuge practiced by plagiarists to hide the source of their inaterial.

Besides narrowing its range of concern to the copying of expression, however, copyright law is not concerned with all expression but merely with protected expression. In other words, copyright infrimgement can occur only when the copied work has met the applicable statutory requireinents of age, registration, or notice. ${ }^{81}$ If the copied work is too

77. Narell v. Freeman, 872 F.2d 907, 911 (9th Cir. 1989) (quoting Salinger v. Randoun House, Inc., 811 F.2d 90, 98 (2d Cir.), cert. denied, 484 U.S. 890 (1987)). Narell is discussed further infra at notes 145-58 and accompanying text.

78. Nichols, 45 F.2d at 122; $c$. Richard A. POSNER, LAw AND Literature 341-42 (1988) (defending the idea/expression dichotony by arguing that ideas are not the creative eleinents in literature, unlike in science or philosophy).

79. See Craft v. Kobler, 667 F. Supp. 120, 124 (S.D.N.Y. 1987) (writing protected by copyright is infringed by a paraphrase that, despite alterations, appropriates the "craft of authorship" of the original).

80. Nichols, 45 F.2d at 121 .

81. At present, a new work by a single author is protected for the lifetime of the author plus fifty years, 17 U.S.C. $\$ 302$ (1988); registration is necessary not for protection but as a prerequisite to a suit for infringement, 17 U.S.C. $\$ 411$ (1988) (though registration tnay take place after the action has been instituted, Frederick Chusid \& Co. v. Marshall Leeinan \& Co., Inc., 326 F. Supp. 1043, 1063-64 (S.D.N.Y. 1971)); and notice is not required but, if given, elininates the defense of innocent infringement, 17 U.S.C. $\S 401$ (d) (1988). 
old to fall under the copyright statute, ${ }^{82}$ was written by a government employee, ${ }^{83}$ or has otherwise lost its protection, it is in the public domain and cannot be infringed. This basic difference between plagiarism and infringement demonstrates that while plagiarisin is a failure of the creative process as manifested in unattributed copying froin any source, copyright law examines the harm that results from copying-concluding in this case that a work not protected by statute cannot be harned.

Although copying even a small amount of an earier work can be plagiarisin, to be copyright infringement the copying must be substantial. Copyright law, like other legal analyses, apphies the doctrine of de minimis non curat lex: the law does not concern itself with trifles. ${ }^{84}$ If the new work is not based in a substantial way, either qualitatively or quantitatively, ${ }^{85}$ on the earher work, or if the appropriated portion of the earlier work was not qualitatively or quantitatively substantial, ${ }^{86}$ there has been no infringement. Although "no plagiarist can excuse the wrong by showing how much of his work he did not pirate,"87 substantial copying is necessary to turn plagiarism in the popular sense into infringement in the legal sense. The law thus looks to the new work and its effect on the earlier work-not to the process of plagiarisin but to its result.

\section{B. Attribution}

The connection of the author's name with the work invokes the essence of the relationship between the creator and the creation. This connection has monetary value in that the copyright, which includes the right to control publication and other exploitation of the work, belongs initially to the author. ${ }^{88}$ There is also noninonetary value to having one's name associated with a work. In a standard commercial publishing agreement, book authors who sell publication rights have little or no control over the editing, design, production, marketimg, or distribution of

82. See 17 U.S.C. $\S \S 302-305$.

83. Id. § 105.

84. Black's Law Dictionary, supra note 10 , at 431 . See generally Ralph R. Shaw, LITERARY Property IN THE UNITED STATES $45-46$ (1950) (de minimis principle in copyright law).

85. See Whelan Assocs., Inc. v. Jaslow Dental Lab., Inc., 797 F.2d 1222, 1245.46 (3d Cir. 1986) (qualitative rather than quantitative similarity can show copyright infringement), cert. denied, 479 U.S. 1031 (1987).

86. See, e.g., Mathews Conveyer Co. v. Palmer-Bee Co., 135 F.2d 73, 84-85 (6th Cir. 1943) (alleged copying of two illustrations out of a thousand in a catalog is not substantial); Hoffman v. Le Traunik, 209 F. 375,379 (N.D.N.Y. 1913) (alleged copying of a few phrases from a vaudeville monologue is not substantial).

87. Sheldon v. Metro-Goldwyn Pictures Corp., 81 F.2d 49, 56 (2d Cir.), cert. denied, 298 U.S. 669 (1936).

88. 17 U.S.C. $\S 201$ (1988). 
their books ${ }^{89}$ - but authors who find this arrangement alienating can gain comfort from the sight of their names on the title page. In noncommercial pubhications, such as scholarly or scientific journals, seeing their names im print-and having their names seen by others-is the only coinpensation authors receive. ${ }^{90}$

Plagiarism, with its lack of attribution, severs the connection between the original author's name and the work. A plagiarist, by falsely claiming authorship of soineone else's material, directly assaults the author's interest in receiving credit. In contrast, attribution is largely irrelevant to a claim of copyright mfringement. Where copying is authorized, the author has no common-law right to attribution; such a right is nonexistent uuless created by contract. ${ }^{91}$ Conversely, imfringement can occur even when a work is properly attributed if the copying is not authorized-for example, a pirated edition of a book produced by soineone who does not own the publication rights.

Even the fair-use doctrine, influential in shaping courts' perceptions of what degree of copying is aeceptable under copyright law, is silent on the question of attribution. Fair use, which allows certain limited uses of copyrighted works without authorization, permits copying of portions of another's work 'for purposes such as criticisin, comment, news reporting, teaching ...., scholarship, or research."92 By making fair use of a work in these ways, the users add something to the material by placing it in an analytical or critical context, thereby inaking it their property in the Lockean sense. ${ }^{93}$

The Copyright Act identifies four factors to consider in making a

89. See WINCOR, supra note 6, at 95-105 (types of book contracts and the allocation of rights between publishers and authors).

90. SHAW, supra note 84 , at 24 .

91. Morton v. Raphael, 79 N.E.2d 522, 524 (Ill. App. Ct. 1948) (" As the author has no inherent common-law right to have his name used in connection with his work, his name may be wholly onnitted from the work, if the proprietor of it sees fit so to do . . . "') (quoting 18 C.J.S. Copyright \& Literary Property \$ 10, at 144); see also Harris v. Twentieth Century-Fox Film Corp., 35 F. Supp. 153, 155 (S.D.N.Y. 1940) (absence of contractual provision for author's credit eliminated "all rights generally known as the moral rights of authors, which rights include the right to credit as author of a work"); De Bekker v. Frederick A. Stokes Co., 153 N.Y.S. 1066, 1068 (App. Div. 1915) ("The plaintiff was not entitled to have his own name appear in the book."). Contra Clemens v. Press Publishing Co., 122 N.Y.S. 206, 208 (App. Div. 1910) (Seabury, J., concurring) ("The purchaser cannot garble it, or put it out under another name than the author's; nor can he omit altogether the name of the author, unless his contract with the latter permits him so to do."). See generally SHAW, supra note 84, at 23-25, 116 (recommending incorporation into copyright law of an author's "right to credit," which would be an incentive to publication as the only form of advertising available to scientists and scholars).

92. 17 U.S.C. $\$ 107$ (1988).

93. See supra note 18; see also Pierre N. Leval, Toward a Fair Use Standard, 103 HARv. L. REV. 1105, 1111 (1990) ("I believe the answer to the question of justification [of fair use] turns primarily on whether, and to what extent, the challenged use is transformative. The use must be productive and must employ the quoted matter in a different manner or for a different purpose from the original."). But see Sony Corp. of Am. v. Universal City Studios, Inc., 464 U.S. 417, 447-55 
determination of fair use: "(1) the purpose and character of the use ...; (2) the nature of the copyrighted work; (3) the amount and substantiality of the portion used in relation to the copyrighted work as a whole; and (4) the effect of the use upon the potential market for or value of the copyrighted work." 94 Plagiarism would seem to be disqualified from being a fair use because its purpose is to mislead, but the other listed factors also enter into the fair-use calculation, ${ }^{95}$ and attribution is the unknown variable. Beyond honoring the author, attribution serves purposes consistent with the critical and scholarly aims of fair use, such as directimg the reader to additional source material. Lack of attribution does not automatically make plagiarism the ultmiate "unfair use," however; indeed, the fair-use defense has been successfully raised where the quoted material bore no attribution. ${ }^{96}$

With its emphasis on the four stated factors, fair use is an explicitly result-oriented doctrine. One judge who has ruled on several well-known fair-use cases wrote, "The inquiry should focus not on the morality of the secondary user, but on whether her creation claiming the benefits of the doctrine is of the type that should receive those benefits."97 The distinction he made between the morality of the user and the nature of the creation is equally a distimction between process and result.

Some legal systems elsewhere in the world view the failure to attribute material to its author as an infringement of the author's "moral rights."98 These rights belong to the author of a creative work regardless of whether the author actually possesses the work or holds the copyright in it, and they reflect a view of creative works as the expression of the personality of their creators rather than as a forn of property. ${ }^{99}$ The elements making up what is called the droit moral include attribution (acknowledgment of authorship), integrity (prevention of deforming

(1984) (home videotaping of copyrighted broadcasts, even in their entirety and unchanged, is fair use when for noncommercial purposes).

94. 17 U.S.C. $\$ 107$ (1988).

95. See Marcus v. Rowley, 695 F.2d 1171, 1176-77 (9th Cir. 1983) (even an educational use is disqualified from the fair-use exception if it is substantial enough); $c f$. Schroeder v. William Morrow \& Co., 566 F.2d 3, 6 (7th Cir. 1977) (copying data in order to save the time needed to verify them independently is not a valid fair use).

96. See, e.g., Narell v. Freeman, 872 F.2d 907, 913-15 (9th Cir. 1989) (unattributed borrowing of material from a nonfiction book for a novel is fair use).

97. Leval, supra note 93, at 1126 (reconsidering, among other cases, Salinger v. Random House, 650 F. Supp. 413 (S.D.N.Y. 1986), rev'd, 811 F.2d 90 (2d Cir.), cert. denied, 484 U.S. 890 (1987), and New Era Publications Int'l, ApS v. Henry Holt \& Co., 695 F. Supp. 1493 (S.D.N.Y. 1988), aff'd on other grounds, 873 F.2d 576 (2d Cir. 1989)).

98. See generally Melville B. Nimmer \& David Nimmer, Nimmer ON Copyright $\$ 8.21$ [A], at 8-254 to 8-263 (1991) ("Moral rights appear to be of greatest importance in France, Germany, and Italy," id. at 8-254 n.1).

99. Charles Clark, Moral Rights-More Than a Matter of Integrity, BookselLer, Sept. 2, 1988 , at 903 . 
changes), disclosure (determination of how and when a work is first made public), and disavowal (withdrawal of a work). ${ }^{100}$

For the last several decades the American copyright community has debated the place of noral rights in United States law. Legislators repeatedly declined to enact noral-rights legislation, and courts disavowed moral rights as a part of copyright law. ${ }^{101}$ In 1989, however, the United States joined the Berne Copyright Convention, ${ }^{102}$ which requires as a minimun that its neenbers protect the noral rights of attribution and integrity. ${ }^{103}$ Nevertheless, the extent of American inoral-rights protection has reinained unclear: the Berne Convention Inplenientation Act, which put the Berne Convention into effect, states that United States adherence to Berne does "not expand or reduce any right of an author" to assert the rights of attribution and integrity in any copyrightable work. ${ }^{104}$ Some commentators beheve that Berne is likely to alter the spirit if not the letter of copyright law and will make courts more syinpathetic to assertions of moral rights as they look to Berne and the decisions of other Berne signatories for guidance. ${ }^{105}$ Moreover, legislators have apparently recognized noral rights to soine extent by amending the Copyright Act to give certain visual artists a limited right of attribution. ${ }^{106}$ As yet, however, protection for the noral right of attribution in

100. See generally Martin A. Roeder, The Doctrine of Moral Right: A Study in the Law of Artists, Authors and Creators, 53 HARv. L. REv. 554, 558-65 (1940).

101. See, e.g., Gilliam v. American Broadcasting Cos., 538 F.2d 14, 24 (2d Cir. 1976) ("American copyright law, as presently written, does not recognize moral rights or provide a cause of action for their violation, since the law seeks to vindicate the economic, rather than the personal, rights of authors."); see also Leval, supra note 93, at 1128 ("Our copyright law has developed over hundreds of years for a very different purpose and with rules and consequences that are incompatible with the droit moral.").

102. Berne Convention for the Protection of Literary and Artistic Works, July 24, 1971, in COPYRight LAWS AND Treaties of THE World (compiled by the United Nations Educational, Scientific and Cultural Organization and the World Intellectual Property Organization 1990), Item H-1, at 1 (Supp. 1972).

103. Id. art. 6 bis.

104. Pub. L. No. 100-568, § 3(b), 102 Stat. 2853 (1988) (codified as amended at 17 U.S.C. $\S 104(\mathrm{c})(1988))$.

105. N1MMER \& N1MMER, supra note 98, § 8.21[A][2][b], at 8-257 to 8-263.

106. The right of attribution was granted to the author of a "work of visual art," defined as "a painting, drawing, print, or sculpture, existing in a single copy, [or] in a limited edition of 200 copies or fewer" or "a still photographic inuage . . . existing niı a single copy . . . or in a limited edition of 200 copies or fewer . . ." Visual Artists Rights Act of 1990, 17 U.S.C.A. § 101(a)(1), (2) (West Supp. 1991). An author's right of attribution includes the right "to claim authorship ... to prevent the use of his or her name as the author of any work of visual art which he or she did not create ... [and] to prevent the use of his or her name as the author of the work of visual art in the event of a distortion, mutilation, or other nodification of the work which would be prejudicial to his or her honor or reputation ...."Id. $\S 106 \mathrm{~A}$. This protection, confined as it is to linited-edition visual works, is far fron a ringing affirmation of authors' noral rights. It does not apply, for exanuple, to audiovisual works such as notion pictures, despite the fervent wish of some artists to prevent colorization of their filıns. 
literary works is not an explicit or established part of United States copyriglit law.

Copyriglit law's insensitivity to the issue of attribution, despite attribution's central place in the definition of plagiarisn, demonstrates once again the law's focus on result, not process. In the popular view, plagiarists sliortchange both themselves and the original authors. In the view of copyright law, the only liarm that counts is the resulting harm to the infringed work, which is nidifferent to claims of authorship that attacli to it. Attribution of autliorship is the highly personal connection between author and work, but the interest that copyriglit protects is the impersonal colmection between owner and property.

\section{Intent}

A common defense to accusations of plagiarisn is the claim of accidental copying, often through faulty notetaking in which original naterial was inadvertently mingled witl material copied froin another source. For example, a professor at the Umiversity of California at Berkeley ascribed the close parallels between the language of a newspaper article lie liad written and another author's journal article on the sanie subject to his practice of writing the article "froin his own reading notes which probably too closely resenibled the original texts." 107 He said liis lack of intent to copy proved that plagiarisn was "not what occurred here. What's occurred here was a dunb mistake." 108 Similarly, a first novehist called the appearance in his book of fifty-tliree passages froin another writer's novel " 'the inost awful mistake, which happened because I made notes fronı various books as I went along and then lost the notebook telling where they came froin." "109

Many would agree that when the copying is genuinely accidental, it is not plagiarisn but just a "1mistake." 110 Given the innitative and assimilative process of learning, it is not surprising when the mind fools itself into forgetting that its thoughts are not entirely original. One president of Cornell University defended himself against a charge of plagiarisn by demonstrating his photographic nemory, which had enabled him to reproduce unintentionally a passage by another author in lis inaugural address. The president recited paragraphs from books chosen at random

107. Alexei Barrionuevo, Prof's Piece: Plagiarism or Mere Blunder?, Dally Californian, Mar. 8, 1991, at 1, 4.

108. Id.

109. MalloN, supra note 16, at 110 (quoting Susan H. Anderson, New Novelist Is Called a Plagiarist, N.Y. TIMES, Oct. 22, 1980, at C7) (internal quotation omitted). For a discussion of Jacob Epstein's plagiarizing in his novel Wild Oats parts of Martin Amis' The Rachel Papers, see id. at 89143.

110. Cf. ST. ONGE, supra note 10 , at 60 ("There must be evidence of intent to deceive and misrepresent authorship. The evidence can be internal and textual or external and circumstantial."). 
from his study shelves, and his listeners cleared him. ${ }^{11}$

Observers and critics are sometimes reluctant to accept the plagiarist's claim of lack of intent, but their reluctance is more likely due to an inability to believe the excuse than to a conviction that accidental copying is equivalent to plagiarism. The Berkeley professor's credibility suffers when one learns that he was not present at the meeting lie so vividly described $^{112}$ because one realizes that he must have known the description in his notes had been written by soineone else. Likewise, the first novelist, an American, must liave known that at least one of the passages he had copied into his notebook was not his own because it contamed a reference to a British advice columnist; in his novel he substituted a reference to Ann Landers. ${ }^{113}$

In the language of the law, intent to deceive would be an element of the offense of plagiarism. Copyright infringement, however, is a strictliability offense: an infringer is liable no matter low the copying came about, regardless of intent or the lack of it. ${ }^{114}$ The law considers not the process that led to the infringement, witl mitigatimg or excusing factors; it considers only the resultimg infringement and pumislies accordingly. The fair-use defense is a umque exception to the strict liability arising from infringement, but even in fair use the court examines sucli resultoriented criteria as the nature and amount of the use, so that to quote inaterial with the best of imtentions can still constitute copyright infringement. ${ }^{115}$

The different views of intent reflected in plagiarism and in infringeinent reflect different understandings of harm. Plagiarism is a diffuse offense agaimst society, harming many participants in the creative transaction. The plagiarist is deprived of experiencing the satisfaction and learning that come from participation in the creative process. The author of the copied work inay suffer financial harm througli a reduction in the salabihty of the original work or reputational harm through a mis-

111. ST. ONGE, supra note 10 , at 6-7.

112. Barrionuevo, supra note 107 , at 1 .

113. MALLON, supra note 16, at 111 (calling this the "smoking gun").

114. Buck v. Jewell-LaSalle Realty Co., 283 U.S. 191, 198 (1931) (hotel owner who transmitted musical radio broadcasts was liable despite his lack of advance knowledge of their content); Shapiro, Bernstein \& Co. v. H.L. Green Co., 316 F.2d 304, 308 (2d Cir. 1963) (sellers of pirated records were liable regardless of their lack of actual knowledge of piracy); Toksvig v. Bruce Publishing Co., 181 F.2d 664 (7th Cir. 1950) (lack of knowledge that the copied materials were original translations does not preelude liability). But see De Acosta v. Brown, 146 F.2d 408, 413-14 (2d Cir. 1944) (Hand, J., dissenting) (publisher who did not know an article was the product of plagiarism by its author should not be liable), cert. denied, 325 U.S. 862 (1945).

115. Wihtol v. Crow, 309 F.2d 777, 781 (8th Cir. 1962) (copyright statute has insufficient "elasticity or flexibility" to make allowances for good intentions). But see New York Tribune, Inc. v. Otis \& Co., 39 F. Supp. 67, 68 (S.D.N.Y. 1941) (although the intent to infringe is not essential to a cause of action for copyright infringement, the defendant's intention "bears upon the question of "fair use" "). 
perception that the original work was instead copied. ${ }^{116}$ Similarly, the original work inay be injured financially or reputationally. The genuine contributions of the new work might be devalued once the work has been tainted as plagiaristic. All writers and scholars inay be disadvantaged by the unfair head start that plagiarists gain over those who do not plagiarize. The public as a whole may be deceived, defrauded, or misinformed.

The law has a narrower conception of the harm caused by infringement. The law limits standing to the copyright owner and measures harm by impairment of that owner's economic interest. The law allows an infrimgement action only where the infringer has benefited and allows recovery only where the value of the original work has been reduced. The law inakes harm part of the "substantial similarity" calculation; if the infrimging work has not harmed the infringed work, the similarity is likely not substantial. The harm the law recognizes is not to the process but to the result alone.

III

Legal Metaphors: Intellectual Property aNd the Creative CONTRACT

Next, o'er his Books his eyes began to roll,

In pleasing memory of all he stole,

How here he sipp'd, how there he plunder'd snug

And suck'd all o'er, like an industrious Bug.

Here lay poor Fletcher's half-eat scenes, and here

The Frippery of crucify'd Moliere....

-Alexander Pope, The Dunciad ${ }^{117}$

Different legal doctrines incorporate process and result to varying degrees. Contract law, for exainple, provides a frainework to govern and define the process by which a contract is formed and interpreted. Property law is less interested in how property caine to be than in identifying its boundaries, its owner, and its value. The choice to treat words as "intellectual property" started the law on a path to evaluating the creative process through scrutiny of its result, which diverges from the popular path to evaluating the creative process through scrutiny of the process itself. With this emphasis on result, copyright law has narrowed its concern with wrongful copying to exclude many instances of plagiarism. The choice of a new legal framework to transcend the limitations of the

116. Cf. Marcus v. Rowley, 695 F.2d 1171, 1173-74 (9th Cir. 1983) (plaintiff, the author of a cake-decorating booklet, learned it had been copied when a reader of her booklet erroneously accused her of plagiarizing the booklet copied from hers).

117. Alexander Pope, The Dunciad, bk. 1, 11. 127-32, in POetry and Prose of Alexander Pope 312 (Aubrey Williams ed., 1969). 
old framework could lead to a more complete legal understanding of creativity by incorporating both result and process.

An often-cited antecedent of copyright law is the story of Samt Columba, who in the year 567 surreptitiously copied a psalmbook belonging to his teacher, Finnian of Moville. When Finnian objected, the dispute went before King Diarmed. The king concluded that both the original and the copy belonged to Finnian, saying, "To every cow her calf, and accordingly to every book its copy."118 Diarmed saw the book as Finnian's property, the ownership of which entitled Finnian to its product, the copy. The king's ruling thus pointed in the direction of the future development of copyright law.

Intellectual-property law arose in the setting of commercial publishing. The inotive force behind legal protection for published works did not emanate from authors, scholars, and scientists; it came from booksellers, printers, and publishers. After the popularization of the printing press in the mid-1400s, printers proliferated and became increasingly competitive in a world where hiteracy was limited and book production outstripped demand. During the 1500 s the government of England placed legal controls on the printing industry, ostensibly to prevent the piracy of printed works by rival printers but motivated largely by the desire to prevent the publication of books challenging royal or church authority. For the next hundred years, the state permitted the printing of books or pamphlets only by license. ${ }^{119}$ The first intervention of the law into the book trade, then, was not on behalf of the author to estabish a connection to the work but on behalf of the state to regulate the printer's right to copy.

Not until the Statute of Anne im 1710 did the law fornally recoguize authors as well. Until that time writing had been seen as either the occupation of gentleinen of leisure, who had independent sources of imcome and who felt that acceptance of money for their writing would be beneatl them, or of men of less noble birth who sought support froin wealthy patrons. ${ }^{120}$ Having little bargaining power, writers had to accept whatever printers and booksellers were willing to pay them for selling copies of their works. ${ }^{121}$ The Statute of Anne, drafted in part by Jonatlian Swift, gave authors the exclusive right to print new works for fourteen years, renewable for fourteen more years, and the exclusive right

118. Philip Wrtrenberg, The Protection of Literary Property 7 (rev. ed. 1978); see also LINDEY, supra note 14, at 101 (recounting the story of Saint Columba and citing Finnian $v$. Columba as the first reported copyright case).

119. WITTENBERG, supra note 118 , at 10-22.

120. Id. at $22-28$.

121. Id. at $24,26-27$. 
to pubhish existing works for twenty-one years. ${ }^{122}$ With this development, for the first time, "[t]he notion that the author had always had a common-law right in his property found legal recognition."123 The subsequent development of copyright law in England and the United States has built upon this notion that the relationship between authors and their writings is that of owners to their property.

The law's categorization of written material as property springs from the behief that the "law of nature" entitles huinan beings to reap the fruits of their labors. ${ }^{124}$ According to Blackstone:

When a man by the exertion of his rational powers has produced an original work, he has clearly a right to dispose of that identical work as he pleases, and any attempt to take it from him, or vary the disposition he has made of it, is an imvasion of his right of property. ${ }^{125}$

Thus, an essential attribute of property in the Anglo-American legal system is exclusivity of ownership. Property is "[t]hat which is peculiar or proper to any person; that which belongs exclusively to one."126 The owner of property has "the unrestricted and exclusive right to a thing; the right to dispose of a thing in every legal way, to possess it, to use it, and to exclude every one else from interfering with it."127 Certain kinds of property, such as natural resources, are not subject to exclusive use, ${ }^{128}$ but these are exceptions to the general rule of exclusivity.

If words are property, they are an odd form of property. At any instant they are finite in number and yet can be freely and infinitely invented or duphicated. They cannot be marked with the insignia of ownership. When first imvented they are subject to exclusive possession before being written or uttered, yet such exclusive possession leaves thein incapable of fulfilling their cominunicative function. They can be initially withheld from others, but once transmitted, they can never be retrieved. They are used to convey meanings that have developed over

122. Alan Latman et al., Copyright for the Nineties: Cases and Materials 2-3 (3d ed. 1989); WITTENBERG, supra note 118, at 28.

123. WTTTENBERG, supra note 118 , at 29.

124. 1 William Blackstone, Commentaries *405-06.

125. 1 Id.

126. BLACK's LAW DictionaRY, supra note 10, at 1216; see also Washington Medical Ctr., Inc. v. United States, 545 F.2d 116, 125 (Ct. Cl. 1976) (quoting similar definition of "property" from BLACK'S LAW DictionARY 1382 (4th ed. 1968)), cert. denied, 434 U.S. 902 (1977).

127. Black's LAW Dictionary, supra note 10, at 1216; see also People v. Martinez, 250 N.Y.S.2d 28, 31 (Crim. Ct. 1964) (quoting similar definition in an earlicr edition of Black's Law Dictionary); Oliver Wendell Holmes, JR., The Common Law 246 (Boston, Little, Brown 1881) ("Within the limits prescribed by policy, the owner is allowed to exercise his natural powers over the subject-matter uninterfered with, and is more or less protected in excluding other people from such interference. The owner is allowed to exclude all, and is accountable to no one.").

128. See Joseph L. Sax, The Public Trust Doctrine in Natural Resource Law: Effective Judicial Intervention, $68 \mathrm{MICH}$. L. REV. 471 (1970) (legal concept of property rights in natural resources, specifieally water, as held in trust by government for the general public). 
centuries but can be instantly shifted in fresh and surprising ways. Themselves composed of alphabetical symbols, they are of little value when separated from the larger matrix of hiterature in which they are the symbols.

Courts and legal scholars have long recognized that literary property differs from other forms of property. Justice Holmes remarked upon the unusual qualities of this variety of intangible property:

The notion of property starts, I suppose, from confirmed possession of a tangible object and consists in the right to exclude others from interference with the more or less free doing with it as one wills. But in copyright property has reached a more abstract expression. The right to exclude is not directed to an object im possession or owned, but is in vacuo, so to speak. It restrains the spontaneity of men where but for it there would be nothing of any kind to hinder their doing as they saw fit. It is a prohibition of conduct remote from the persons or tangibles of the party having the right. It may be infringed a thousand miles from the owner and without his ever becoming aware of the wrong. It is a right which could not be recognized or endured for more than a limited time, and therefore, I may remark in passing, it is one which hardly can be conceived except as a product of statute, as the authorities now agree. ${ }^{129}$

Judge Seabury noted that the purchaser of hiterary property has more circumscribed abilities to use it than does the purchaser of other kinds of property:

Even the matter of fact attitude of the law does not require us to consider the sale of the rights to a hiterary production in the saine way that we would consider the sale of a barrel of pork. . . . The man who sells a barrel of pork to another may pocket the purchase price and retain no further interest in what becomes of the pork. While an author may write to earn his living and may sell his hiterary productions, yet the purchaser, in the absence of a contract which permits limi so to do, cannot make as free a use of it as he could of the pork which he purchased. ${ }^{130}$

Nevertheless, such judicial discomfort has not interfered with the law's readiness to treat what it calls "intellectual property" as it treats other forms of property. ${ }^{131}$ Copyright law has duphicated the protection provided by traditional property doctrimes by setting statutory boundaries similar to the physical boundaries of tangible property and by formulating exclusive rights of ownership, such as the right to exclude, to use,

129. White-Smith Music Publishing Co. v. Apollo Co., 209 U.S. 1, 19 (1908) (Holmes, J., concurring), superseded by statutes as stated in Apple Computer, Inc. v. Franklin Computer Corp., 714 F.2d 1240 (3d Cir. 1983).

130. Clemens v. Press Pnblishing Co., 122 N.Y.S. 206, 207-08 (App. Div. 1910) (Seabury, J., concurring).

131. "Nothing can with greater propriety be called a man's property than the fruit of his brain.'" Waring v. Dunlea, 26 F. Supp. 338, 340 (E.D.N.C. 1939) (quoting CoPINGER's LAw of COPYRIGHT I (5th ed.)). 
and to transfer. ${ }^{132}$

In terms of an author's commercial concerns, the notion of intellectual property is both appealing and appropriate. It provides a conceptually simple model on which to base legal analysis, and it accounts for the economic interests at stake. If a poem is property, people can buy and sell it, inherit it, or otherwise transfer it. It has a legal existence separate froin its author and from which the author can benefit.

But authors also have noneconomic imterests to which the notion of intellectual property corresponds less well. People who make an illuminatimg discovery, write a profound and beautiful essay, or invent a trenchant epigram inay want less to own their creations than to receive credit for them. Ownership would give them the ability to withhold their contributions froin others, but what most authors want is to communicate them. ${ }^{133}$ Intellectual-property law does not provide a useful framework to govern this commumication or to ensure that creators receive full credit for their creations when the communication occurs.

The law's choice of the property framework for words was not an mevitable one. As first-year law students learn, the law encompasses a variety of doctrinal areas, each with its own terminology, lines of cases, rationales, and expressed values. Some doctrimes, such as contracts, deal largely with plamied interactions between people; others, such as torts, deal largely with interactions that are unplamed; still others, such as property, deal largely with the objects of those interactions.

Despite their differences, all legal doctrines share their identity as metaphors. They reflect various ways of seeing the world, each way incoinplete by itself but overlapping with and complementary to the others. In combination, these metaphors are more effective than they are singly. For example, adding the spontaneity of torts to the deliberateness of contracts produces a more accurate picture of the spectrum of human interactions than would either alone.

Yet all too often legal metaphors are not used in coinbination to enlarge our understandmg but in isolation to constrict it. A metaphor can distort our analysis by squeezing it into a mold for which it is not

132. See Gordon, supra note 27, at $1354-94$ (refuting the misconception that copyright has deviated from common-law property principles by imposing uniquely intrusive restraints).

133. That ownership is imconsistent with communication is revealed by the reasoning of Justice Yates, in the famous English decision of Millar $v$. Taylor, which has been summarized as follows:

I may call an idea "mine" (he reasoned) only while I keep it to myself. But when I communicate that idea to you, it becomes "our" idea; for I camiot thereafter prevent you from thinking it or nsing it at your pleasure. Indeed, my very act of communicating the idea to you negatives the existence of any intention on uny part to withhold it from you. When an author publishes his work, he commumicates his ideas to the world at large. He thus makes a present of his ideas to the public. Thereupon those ideas become the common property of all.

John F. Whicher, The Creative ARTS and the Judicial Process 118 (1965) (paraphrasing Millar v. Taylor, 4 Burrow 2303, 98 Eng. Rep. 201 (K.B. 1769) (Yates, J., dissenting)). 
suited. ${ }^{134}$ The power of a metaphor to shape our understanding is profound, and yet, as Robert Frost said, "All metaphor breaks down somewhere."135 Judge Frank has also cautioned us about labels, which

"can have immense consequences. ... Stressing a newly perceived hike-

ness between many particular happenings which had theretofore seemed unlike, [the label] inay blind us to continning unlikeuesses. Hypnotized by a label which emphasizes identities, we may be led to ignore differences. ... For, with its stress on uniformity, an abstraction or generalization tends to become totalitarian in its attitude toward uniqueness."136

The metaphor of intellectual property is capable of distorting the law's analysis of human creativity. When we talk carelessly about intellectual property, we reduce a voluminous, diverse mixture of stray thoughts, dogged research efforts, fragmentary phrases, epics, stunning insights, and blind alleys to mere cominodities. Property is thought of as being subject to exclusive ownership, over and over, in sequence. But each creative act takes place within a web of contributions from a commumity of creators, ${ }^{137}$ a web that spans both time and space. The property metaphor is misleading for words because words are ineant to be shared, not possessed. Words-as well as music and the visual and performing arts-are a medium of commumication. ${ }^{138}$ As such, they are subject to rejection, misunderstanding, or distortion during their passage from creator to audience, as well as to recognition, appreciation, or improvement. What they are not subject to is ownership.

To improve our legal metaphor we inust look beyond the idea of property as something we possess to the larger legal context within which property exists. Property is more than an aggregation of separate chains of ownership. It is a network of relationships, constantly realigned and

134. Cf. Patricia Williams, The Obliging Shell: An Informal Essay on Formal Equal Opportunity, 87 MiCH. L. REV. 2128, 2130-32 (1989) (pointing out the pitfalls of "sausage analysis," in which ingredients, no inatter how aberrant or grotesque, put into a sausage-making inachine are labeled "sausage" when they emerge at the other end).

135. Robert Frost, Education by Poetry, reprinted in RoBert A. Greenberg \& James G. HEPBURN, ROBERT FROST: AN INTRODUCTION 82-83 (1961), quoted in Whicher, supra note 133, at 78 . Frost preceded this statement with the advice that

unless you have had your proper poetical education in the inetaphor, you are not safe anywhere. Because you are not at ease with figurative values: You don't know the metaphor in its strength and its weakness. You don't know how far you inay expect to ride Id.

it and when it inay break down with you.

136. Granz v. Harris, 198 F.2d 585, 590-91 (2d Cir. 1952) (Frank, J., concurring) (objecting to the term "Moral Right") (quoting Guiseppi v. Walling, 144 F.2d 608, 618-19 (2d Cir. 1944), aff'd, Geinsco, Inc. v. Walling, 324 U.S. 244 (1945)).

137. Cf. Carol Gilligan, In a Different Votce: Psychological Theory and Women's DEVELOPMENT 24-63 (1982) (contrasting the "hierarchy of rights" with the "web of relationships").

138. 'The heart of language is not 'expression' of soinething antecedent, inuch less expression of antecedent thought. It is coinınunication; the establishınent of cooperation in an activity in which there are partners, and in which the activity of each is modified and regulated by partnership." JoHN DEWEY, EXPERIENCE AND NATURE 179 (1925). 
readjusted through transactions that the law understands as contracts. The contract metaphor adds to the intellectual-property metaphor because it focuses as much on the process of the transaction as on the result. It assumes the existence of dealings between people, unlike the property metaphor, which assumes the existence of a bundle of rights that an owner holds against others. Contract is a meeting of minds, not a placing of boundaries.

Some political philosophers-most notably Hobbes, Locke, and Rousseau ${ }^{139}$-have theorized that societies are based on an implicit "social contract" in which people cone together in communities to gain the benefits of safety, security, and support, and in exchange relinquish their freedom to behave exactly as they choose. The laws of the community become the expression of its social contract-its common language, the system of words that enables its members to communicate. This metaphor may lack historical validity, and may make unwarranted assumptions about the contract's binding power, but it at least recognizes that society is a collection of human beings whose hives are spent in interactions with one another.

As the social contract is a metaphor for political life, perhaps another kind of contract is a metaphor for efforts at creativity and conmumcation: the "creative contract." Those who enter into the creative contract recognize that the creative result is inseparable from the process of creation and that a creation is mcomplete until it is commuiricated. By virtue of hiving among other people, everyone is a party to the creative contract as both a creator and a member of the audience. Creators promise to offer their efforts with honesty, smcerity, and care; audiences promise to accept their efforts in the same spirit.

Thimking of creativity in terms of this larger social relationship and viewing infractions against hiterary ethics, such as plagiarism, as breaches of the creative contract as well as infrimgements of property rights can open new avenues of legal analysis. Intellectual property is an inadequate metaphor not because the structure of property law is inadequate but because the term itself makes people think too simplistically of words as property to be owned. The contract metaphor reminds us that property can be shared, exchanged, bargained over, and used, as well as owned.

Where property law is defensive, contract law is facilitative. Contract law anticipates imperfections im dealings between people and provides ways to interpret and resolve these imperfections. This new way of thinking about copyright disputes could bring more information into our

139. See Thomas Hobbes, Leviathan (C.B. MacPherson ed., Penguin Books 1951) (1651); Locke, supra note 18; Jean Jacques Rousseau, The Social Contract and Discourses (G.D.H. Cole trans., E.P. Dutton 1950) (1762). 
legal decisions. Instead of restricting our inquiry to rights expressly granted by contract in particular transactions, ${ }^{140}$ we could consider the broader inplications of the creative contract, in the saine way that the law of contracts considers common understandings and "usage of trade" as implied contract terms. ${ }^{141}$ For exainple, the author's desire for attribution, which has not found secure protection in the intellectual-property regime, could be considered a term of the implied creative contract, along with the other "inoral rights." The traditional legal reluctance to examme the artistic inerit of a work-hard to explain under the property-law regime that allows ineasureinents of the value of propertywould become consistent with the reluctance to ineasure the adequacy of the consideration in a bargain. ${ }^{142}$ After all, there is no way to force a creator to be inspired, and the law is correct in refusing to draw lines between the meritorious and the inferior. But the law can draw lines between a creative exchange attempted in good faith and one that is flawed. ${ }^{143}$ Most important, the law could look beyond tlie parties immediately involved in a transaction to assess a decision's impact on the larger creative community, the third-party beneficiary of the transaction. This kind of policy analysis is entirely consistent with copyright law's recognition of responsibility to society as a whole as well as to mdividual creators. ${ }^{144}$

Some courts, while holding to the property metaphor, have broadened their inquiries in ways consistent with the contract metaphor. Irena Narell, the author of a book about the history of Jewish families in the San Francisco Bay area, accused historical novehst Cynthia Freenan of having plagiarized her nonfiction book, and sued for copyright infrimgeinent. ${ }^{145}$ The Court of Appeals for the Ninth Circuit, reviewing the dis-

140. See, e.g., Edison v. Viva Int'l, Ltd., 421 N.Y.S.2d 203, 206 (App. Div. 1979) ("so-called 'moral right' is controlled by the law of contract"); see also Granz, 198 F.2d at 588 (in the absence of a contractual provision to the contrary, a record producer could sell recordings abbreviated from master discs); Vargas v. Esquire, Inc., 164 F.2d 522, 525-26 (7th Cir. 1947) (no right to attribution for illustrations where artist had entered into contract divesting him of any "right, claim or interest" in the illustrations); Harris v. Twentieth Century-Fox Film Corp., 43 F. Supp. 119, 121 (S.D.N.Y. 1942) (coauthor of a screenplay retained no right to screen credit after contracting to sell all property rights); $c f$. cases cited supra note 91 (in which authors were deried the right of attribution for works sold absent contractual provisions creating such a right).

141. See generally RESTATEMENT (SECOND) OF CONTRACTS $\$ 222$ (1979) (defining usage of trade as "a usage having such regularity of observance in a place, vocation, or trade as to justify an expectation that it will be observed with respect to a particular agreement" and commenting on determination of and weight given to this usage in contract interpretation).

142. See generally id. at $\$ 79 \mathrm{cmt}$. c ("Ordmarily ... courts do not inquire into the adequacy of consideration.").

143. Cf. Wood v. Lucy, Lady Duff-Gordon, 118 N.E. 214 (N.Y. 1917) (finding promise of "reasonable efforts" implied in employment agreement and evaluating whether such promise was fulfilled).

144. See supra note 52 and accompanying text.

145. Narell v. Frecman, 872 F.2d 907 (9th Cir. 1989). 
trict court's grant of summary judgment for Freeman, presented its analysis in terms of traditional intellectual-property principles. Although Freeman had “admitted consulting Narell's book during her research and taking "language' from it," 146 the court found that there had been no copying of protected expression; the copying was inerely of facts and of "ordinary phrases." 147 Then, having already found sufficient grounds to uphold the grant of summary judgment on the basis that there had been no wrongful copying, the court went on to buttress its conclusion by holding in addition that the two works were not substantially similar ${ }^{148}$ and that Freeman had inade fair use of Narell's history. ${ }^{149}$

The conduct in Narell $v$. Freeman is a paradigm of the differences between plagiarism, which perhaps it was, and copyright infringement, which it was not. The court deemed the copying that unquestionably took place to be legally insignificant because the material copied was not expression and because it was insubstantial in both quantity (consisting of some three hundred words out of a full-length book) and quality (consisting merely of "background material" not "at the heart" of the book). ${ }^{150}$ Failure to attribute the copied inaterial to its original authora hallmark of plagiarism-did not invalidate Freeman's fair-use defense to infringeinent. ${ }^{151}$ And even though Freeman said she had used Narell's book during her research and some of the phrases in her book had "undoubtedly" coine from Narell's, this intentional copying was not infringement, primarily because the market for the original work had not been harmed. ${ }^{152}$

Yet the court's analysis was informed by factors more closely related to plagiarism than to infringeinent-factors more closely related to the creative contract than to intellectual property. At first, in standard intellectual-property fashion, the court dutifully turned its attention to the characteristics inherent in the copied work itself, illustrating its holding that the copied language was so ordinary as to be unprotectible with the imphication that copying the phrase "crawling with alligators" was the only way to avoid such awkward paraphrases as "populated by sluggish, broad-headed loricates."153

Later in its consideration of whether the copied inaterial was protectible, however, the court looked to characteristics of the creative
146. Id. at 910 .
147. Id. at 911-12.
148. Id. at $912-13$.
149. Id. at 913-15.
150. Id. at 909,913 .
151. Id. at 914-15.
152. Id. at 910, 914-15.
153. Id. at 911 . 
transaction that had taken place between Narell and Freeman when Freeman used Narell's book as a source of historical information. Unlike a hypothetical author who might copy lines directly from Longfellow's poem "Paul Revere's Ride" to use in her own poem, Freeman drew from Narell's history " $\mathrm{m}$ creating an entirely different kind of story." 154 In its analysis of the question of substantial similarity, the court again returned to the "fundamental differences" between Narell's work of history and Freeman's work of fiction. ${ }^{155}$ As a concurring opinion pointed out, the court, having found no wrongful copying, did not need to reach the question of substantial similarity at all. ${ }^{156}$ Its insistence on reaching that question allowed it to further explore the nature of the interaction between the two authors, perhaps motivated by an underlying conviction that indeed the purpose of a nonfiction book is to serve as a reference source for later works. In this discussion the court shifted its focus to what Freeman did, not what she produced.

The court again turned its attention from result to process when it considered the matter of attribution. It raised the issue in its discussion of fair use, statimg that the purpose and character of the use weighed "heavily against Freeman because she did not acknowledge in her work that she had consulted Our City in writing Illusions."157 Later the court imphed that an "honorable" author would "acknowledge sources."158 This hint that attribution would have been appropriate suggests one way in which contract principles can enrich the law of creativity. To avoid allowing a plagiarist an unearned benefit from the work of another, attribution should be a part of the intplied contract between two writers.

The troublesome issue of self-plagiarism, whicli primarily harms the audience rather than the autlior, also demonstrates the usefulness of the contract metaphor to enlarge and supplement the law's intellectual-property metaphor. Self-plagiarism occurs when a work echoes an earlier work by the same autlior. Such an echo appears in two works on the economics of copyriglit law by Judge Posner, an advocate of lessened copyright protection. ${ }^{159}$ Because botli the memory and the inventive

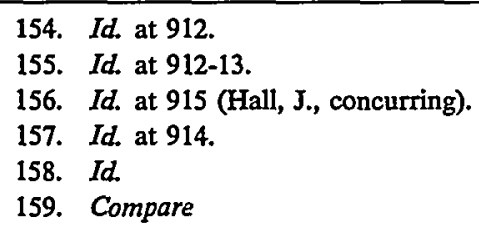

The difficult case is that of the noncritical parody, perhaps better described as "burlesque." It is best illustrated by Jack Benny's burlesque of Gas Light. Benny was not making fun of Gas Light the way "Myra Buttle" was making fun of The Waste Land, any more than Abbott and Costello were making fun of Frankenstein or Dracula in Abbott and Costello Meet Frankenstein. Humorous but not ridiculing versions of the original, these burlesques are derivative works in a pure form, and modern copyright law gives the copyright holder the exclusive right to make such works. A derivative work is a substitute, though an imperfect one, for the original; it may therefore siphon revenues from the original work not 
powers of even the most brilliantly creative mind are limited, some degree of repetition within the works of a single author is inevitable. It becomes objectionable only when it results from laziness or the desire to mislead.

Of all the varieties of plagiarism, self-plagiarism corresponds most closely to copyright infringement because at least one of the three areas of divergence between the two concepts vanishes entirely. The key element of self-plagiarism is the act of copying. Intent is less at issue, for authors would be unlikely to copy their own earhier works to a noticeable extent without meaning to do so. Attribution is not at issue at all, for in self-plagiarism the misrepresentation is not of authorship but of the novelty of the copied work. An author who repeats inaterial in two different published works is not deceiving the reader about who wrote the material. The deception is of readers who mvest time or money in a work with the expectation that its contents are different from, or at least differently expressed than, the contents of the author's other works. These readers are left feeling that they have received less than they had barganied for.

A copyright infringement suit will never result from self-plagiarism unless the copyright of the earlier work belongs to someone other than the copyriglit owner of the later work. For exaniple, in 1984 the inusician Jolin Fogerty wrote a song reminiscent of one he had written in 1970. Fogerty had sold all rights to the earhier song, and the purchaser of those rights brought a lawsuit for copyright infringement against

\footnotetext{
by disparaging that work but by satisfying part of the demand for it. So maybe the law should try to distinguish between parody and burlesque and treat the latter but not the former as infringing. The difficulty of doing this should be obvious. Yet the law may already be doing it implicitly by the emphasis it places on whether the allegedly infringing work is fulfilling the demand for the original work (which a parody does not do); if so it is a derivative work, and infriuging.

PosNer, supra uote 78, at 350-51 (footnotes omitted) with

A difficult case is that of the noncritical parody, perhaps better described as "burlesque" and well illustrated by Jack Beimy's famous burlesque of Gas Light. Benuy was not attacking Gas Light any more than Abbott and Costello were attacking Frankenstein in Abbott and Costello Meet Frankenstein. Humorous but not ridiculing versions of the original, these burlesques are derivative works im a pure form, and modern copyright law gives the copyright holder the exclusive right to make such works. A derivative work is a substitute, though an imperfect oue, for the original; it may therefore siphon revenues from the origual work not by disparaging that work but by satisfying part of the demand for it. So maybe the law should try to distinguish between parody and burlesque and treat the latter but not the former as mfringing. The difficulty of doing this should be obvious. Yet the law may already be doing it implicitly by the emphasis it places on whether the allegedly infringing work is fulfilling the demand for the original work (which a parody does not do); if so it is a derivative work and infringing.
}

William M. Landes \& Richard A. Posuer, An Economic Analysis of Copyright Law, 18 J. LEGAL STUD. 325, 359-60 (1989) (footnotes omitted). Neither source cites the other, and while the book's copyright notice names the President and Fellows of Harvard College, the article's copyright notice names the University of Chieago. 
Fogerty and the distributor of the second song. ${ }^{160}$ The infringement action eventually foundered upon the plaintiff's failure to show substantial similarity between the two songs. ${ }^{161}$

In the 1950s Dashiell Hammett was accused of self-plagiarism by the film studio that owned motion-picture rights to his book The Maltese Falcon. ${ }^{162}$ The studio claimed that Hammett's use of some of the same characters in a later detective story with a similar plot infringed its copyright. The court analyzed the problem according to property principles, reasoning that because the grant of motion-picture rights did not include specific language granting exclusive character rights as well, the author retained those rights. In dictum, the court went on to state that characters are not protectible by copyright unless they "really constitute[ ] the story being told."163 Subsequent courts have struggled to differentiate characters that are protectible by copyright from those that are not. ${ }^{164}$

Use of the contract metaphor would have shifted the court's inquiry from the property-based question "Was the second work a copy?" to the contract-based question "Was the second work copied?" This latter question, focusing on process, would have prompted the court to think about the transaction between the audience and the creator. The harm in self-plagiarism is to the audience, not the creator-Hammett himself would not have used the same characters in more than one story if he had had any objection to doing so. Rather than looking at the creative result to determine whether it was copyrightable or infringing, the court could have looked at the creative process itself. Examining the creative contract between Hammett and the audience could have helped the court to understand the contract between Hammett and the studio. What was implied by Hammett's transfer of the motion-picture rights to his book? Did the audience expect Hammett never again to write about the saine characters? Did the audience expect him never to write another detective story? Did the audience rely on misrepresentations by Haininett as to the content or novelty of his new story? Was the copying done as part of the process of producing a story that enhanced the earlier story, or was it done to harm, mislead, or defraud? The answers to these questions would have allowed the court to reach the saine result-no

I60. Fantasy, Inc. v. Fogerty, 654 F. Supp. 1129 (N.D. Cal. 1987).

161. Katherine Bishop, $A$ Victory for the Creative Process, N.Y. Times, Nov. 11, 1988, at B5.

162. Warner Bros. Pictures, Inc. v. Columbia Broadcasting Sys., Inc., 216 F.2d 945 (9th Cir. 1954), cert. denied, 348 U.S. 971 (1955).

163. Id. at 950 .

164. See, e.g., Silverman v. CBS, Inc., 870 F.2d 40 (2d Cir.) (Amos and Andy protected by copyright), cert. denied, 492 U.S. 907 (1989); Filmvideo Releasing Corp. v. Hastings, 668 F.2d 91 (2d Cir. 1981) (Hopalong Cassidy protected); Walt Disney Prods. v. Air Pirates, 581 F.2d 751 (9th Cir. 1978) (Disney cartoon characters protected), cert. denied, 439 U.S. 1132 (1979). See generally E. Fulton Brylawski, Protection of Characters-Sam Spade Revisited, 22 BULL. CoPYRIGHT Soc'Y 77 (1974). 
infringement-without having to attempt the impossible task of defining the boundaries of protectible intellectual property.

The contract metaphor, like all legal metaphors, can become harmful if used to eliminate difficult questions rather than illuminate them. But the law need not discard its metaphors; it can benefit from transforming or combining them. Holding to the intellectual-property metaphor, the Supreme Court has roundly rejected ${ }^{165}$ the suggestions by commentators in a variety of contexts that the protection and consequent financial imterest granted by copyright should be based on the labor invested ${ }^{166}$ - the process, not the result. By looking to the contract metaphor, the law could take the process into account as well. When an author begins to write, there is never a guarantee of what the result will be. The law's goal should be to safeguard the process by rewarding those who undertake to create a work according to the terms of the creative contract.

\section{IV}

\section{ALternatives}

Plagiarism? the hell with itl I thoroughly believe Rostand swiped my friend's play. But Rostand made it into a beautiful thing, didn't he, so what's the odds?

-George Jean Nathan ${ }^{167}$

I left publishing and was in my second year of law school when I received a telephone call from a former coworker. He was considering the purchase of publication rights to a manuscript that happened to have been written by the author whose plagiarism I had uncovered a few years before. My coworker had never heard that story, but a mutual friend who had heard it had told him he ought to talk to me. Hadn't I once edited a book by this author? my coworker asked. Had I liked the book? What had the author been like to work with?

By then I knew enough about copyright law to understand why the pubhisher's lawyers had been so unconcerned. Copying five peripheral paragraphs from three books totalling some eight hundred pages altogether was substantial in neither quantity nor quality. Even had the authors of the copied passages bothered to bring an infringement action, they would most likely have lost.

Yet, describing my experience, I felt fresh anger, not at the lawyers or the law but at the author and the publisher. By writing the book the

165. Feist Publications, Inc. v. Rural Tel. Serv. Co., 111 S. Ct. 1282, 1295 (1991).

166. See, e.g., Ginsburg, supra note 76, at 1898-99 (advocating protection under the "sweat of the brow" theory).

167. WITTENBERG, supra note 118, at 130 (quoting George J. Nathan). Nathan, the drama critic, was commenting on the accusation of plagiarism made against Edmund Rostand for his play Cyrano de Bergerac. See also LiNDEY, supra note 14, at 128-29. 
way he had, the author had breached the duty he had assumed under the creative contract - to synthesize information obtained from many sources into a fluid, coherent whole-and nevertheless received a financial reward as well as authorial credit that reinforced his status as a professional writer, a status that had helped him to earn a living in a competitive field. By silently accepting the author's excuses and publishing the book anyway, the publisher had becone a conspirator in the author's scheine to distort the creative process.

Now the questions in my mind were about both hiterary ethics and the law. I wondered how the law should protect creativity. What could an understanding of plagiarism add to an understanding of copyright law, and what could an understanding of copyright law add to an understanding of plagiarism?

In answering these questions, it would be helpful to consider the social goals that the law is to implement. Perhaps we imagine a society in which creative people are free to exercise their talents without overly burdensome restrictions; im which the public can enjoy the fruits of creative labors; and in which the disappointed or untalented are not tempted to inisuse the law to bring the creative process of others to a halt. ${ }^{168}$

In pursuit of these goals, we can strive to make the law more true to the creative process. Copyright law should open itself to a broader way of understanding words. We have seen that copyright law does not prohibit all copying, including some varieties of plagiarism. Copyright infringement fails to correspond to plagiarism because there is more than one way to view words. In copyright law, words are property, the result of the creative process. In plagiarism, words are part of the process itself, and the process is of both creation and cominumication. Ultimately, these two concepts-process and result-are inseparable.

By looking beyond the tangible form of a book as a "product," courts have already demonstrated their ability to fornulate analyses that comprehend the special nature of words. In the latest in a series of fruitless attempts to impose strict hability on publishers for the information contained in their books, ${ }^{169}$ two mushroom hunters who had becoine

168. The danger of malicious or deluded accusations of plagiarism is substantial. One court noted "that obsessive conviction, so frequent among authors and composers, that all similarities between their works and any others which appear later must inevitably be ascribed to plagiarism." Dellar v. Samuel Goldwyn, Inc., 150 F.2d 612, 613 (2d Cir. 1945), cert. denied, 327 U.S. 790 (1946); see also sources cited supra note 33.

The plaintiff in Arnstein v. Porter, 154 F.2d 464, 467 (2d Cir. 1946), became well known in the courts for his repeated allegations of plagiarism by such famous composers as Cole Porter. See LINDEY, supra note 14, at 193-98 (Arnstein's six unsuccessful lawsuits).

169. See, e.g., Jones v. J.B. Lippincott Co., 694 F. Supp. 1216 (D. Md. 1988) (nursing student injured by self-treatment with remedy listed in nursing textbook); Lewin v. McCreight, 655 F. Supp. 282 (E.D. Mich. 1987) (plaintiffs injured by explosion while following instructions in metalsmithing book); Roman v. City of New York, 442 N.Y.S.2d 945 (Sup. Ct. 1981) (family planning organization 
seriously ill from eating poisonous mushrooms sued the publisher of a mushroom guide they had used. ${ }^{170}$ Declining to apply products-liability standards, the Ninth Circuit differentiated the physical object called a book from the ideas and expression contained within it: "The first may be a product, but the second is not."171 The court based its reasoning on the "high priority [of] the unfettered exchange of ideas. We accept the risk that words and ideas have wimgs we cannot chp and which carry them we know not where. The threat of liability without fault . . could seriously inhibit those who wish to share thoughts and theories."172

By recognizmg that books are more than products, and that words are more than property, courts can be more sophisticated in their approach to creative disputes than they are at present. At first glance, the legal definition of originality would appear to incorporate an understanding of the weblike complexity of the creative process by excluding "noveity" as a relevant attribute. Copyright law imsists that "originality" means merely that a work "owes its origin" to the creator; 173 in other words, it is the result of its author's labors, but it need not be novel. ${ }^{174}$ Courts steadfastly refuse to assess a work's novelty or intrinsic merit. ${ }^{175}$ Indeed, with its emphasis on precedent, the law is predisposed to regard the lack of novelty as a virtue.

Yet the concept of novelty constantly recurs in copyright law. "Original, as the term is used in copyright, means only that the work was independently created by the author (as opposed to copied from other works), and that it possesses at least some minimal degree of creativity." 176 Though the meaning of "creativity" in this context is hard to

not liable for misstatement in contraceptive pamphlet); Walter v. Bauer, 439 N.Y.S.2d 821 (Sup. Ct. 1981) (student injured performing science project described in textbook); Sunith v. Linn, 563 A.2d 123 (Pa. Super. Ct. 1989) (death of dieter who followed instructions in diet book), aff'd, 587 A.2d 309 (Pa. 1991).

170. Winter v. G.P. Putnam's Sons, 938 F.2d 1033 (9th Cir. 1991).

171. Id. at 1034 .

172. Id. at 1035; see also Appellee's Brief at 9, Winter v. G.P. Putnam's Sons, 938 F.2d 1033 (9th Cir. 1991) (No. 89-16308) ("'Ideas hold a privileged position in our society. They are not equivalent to commercial products. Those who are in the business of distributing the ideas of other people perform a unique and essential function." " (quoting Cardozo v. True, 342 So. 2d 1053, 1056 . 57 (Fla. App. 1977))).

173. Burrow-Giles Lithographic Co. v. Sarony, 111 U.S. 53, 57-58 (1884).

174. "[I]f by soine inagic a inan who had never known it were to compose anew Keats's Ode on a Grecian Uru, he would be an 'author,' and, if he copyrighted it, others might not copy that poem, though they might of course copy Keats's." Sheldon v. Metro-Goldwyn Pictures Corp., 81 F.2d 49, 54 (2d Cir.), cert. denied, 298 U.S. 669 (1936); see also Feist Publications, Inc. v. Rural Tel. Serv. Co., 111 S. Ct. 1282, 1287 (1991) ("Originality does not signify novelty; a work may be original even though it closely resembles other works so long as the similarity is fortuitous, not the result of copying.").

175. See, e.g., Bleistein v. Donaldson Lithographing Co., 188 U.S. 239, 251 (1903) ("It would be a dangerous undertaking for persons trained only to the law to constitute themselves final judges of the worth of pictorial illustrations ...."').

176. Feist, $111 \mathrm{~S}$. Ct. at 1287 (emphasis added). 
specify, ${ }^{177}$ novelty is at least one of its components. The court that found creativity to be lacking in the design of a plastic corsage remarked that the "degree of creativity necessary to define objects as works of art is not supplied through innovations which are solely utilitarian or meclianical,"178 implying that nonutilitarian or nonmeclianical innovations could have evidenced sufficient creativity.

Thus, on one hand the law demes the relevance of novelty; on the other liand the law nonetleless takes note of novelty by qualifying the requirement of "originality" as a condition of copyright protection with the requirement of "creativity," which imcludes "novelty." This qualification once again shifts the focus of legal inquiry from process to result. Though the law defines originality in terms of the process of creation by the author, it defines creativity as a cliaracteristic of the resulting creation. ${ }^{179}$ The law is not comfortable with inquiring into the creative process, and so it prefers to beheve that the finder of fact can unanibiguously trace a work's origins through such methods as examining similarities between it and other works or examining the access its author might have had to other works. ${ }^{180}$ This approach is naive and fails to take into account such difficult questions as how to be sure an author is creating new expression rather than remembering it. Society recoginzes that process and result are one and promotes the best use of the creative process, believing that this will finally lead to the most meritorious results. The law studies only the results, recognizing no difference between the inspired and the ordmary.

The law also assumes that it can separate ideas and facts from their expression. ${ }^{181}$ It regards facts as having an objective existence distinct from the existence of the human beings who discern them. Recently the Supreme Court declared, "The distinction is one between creation and discovery: the first person to find and report a particular fact has not created the fact; he or she has merely discovered its existence." 182 This view of objective truth has been discarded by a variety of different

177. For examples of the "almost total lack of ability on the part of the courts to enunciate reasoning for their findings of creativity or lack thereof which would prove useful in formulating an understanding of what creativity is," see Mitzi S. Phalen, Comment, How Much Is Enough? The Search for a Standard of Creativity in Works of Authorship Under Section 102(a) of the Copyright Act of 1976, 68 NEB. L. REV. 835, 838, passim (1989).

178. Gardenia Flowers, Inc. v. Joseph Markovits, Inc., 280 F. Supp. 776, 781 (S.D.N.Y. 1968),

179. See NimMER \& NiMmER, supra note $98, \S 2.08$ [B], at 2-86 ("Where creativity refers to the nature of the work itself, originality refers to the nature of the author's contribution to the work.").

180. See supra notes $63-66$ and accompanying text.

181. See supra notes $73-78$ and accompanying text.

182. Feist Publications, Inc. v. Rural Tel. Serv. Co., 111 S. Ct. 1282, 1288 (1991); cf. Oliver v. Saint Germain Found., 41 F. Supp. 296 (S.D. Cal. 1941) (treating as fact the contents of a book reportedly dictated by a spirit messenger, and holding the book's factual contents were not protected by copyright). 
schools of twentieth-century legal thought, including positivism, ${ }^{183}$ pragmatism, ${ }^{184}$ postmodernism, ${ }^{185}$ nihilisin, ${ }^{186}$ and Critical Legal Studies, ${ }^{187}$ all of which instead see the existence and content of the discovery as being dependent on the discoverer. Far from subscribing to the idea/ expression or fact/expression dichotomy, those who belong to these schools of thought would say that there is nothing but expression.

The law need not cling to simplifications about the nature of originahity and the nature of truth, drawing endless fine distimctions between different kinds of creative achievements ${ }^{188}$ and forgetting that copyright law, like all law, is about people. By embracing a new metaphor, the law can acknowledge that intellectual property does not exist in isolation but is brought into being by creators who adapt and assimilate the work of others. The contract metaphor can suppleinent the property metaphor without replacing it; contract law furnishes a guide for evaluating the way in which creators create, in the same way that property law furnishes a guide for evaluating what creators create.

Applying legal rules to creative efforts is a delicate task, however, no matter how enlightened the rules inight be, for what the law protects it also controls. The premise of intellectual-property law is the idea that creativity should be encouraged and knowledge sought. In actuality we have soinetimes used the law to suppress creativity and knowledge. Along with admiration and awe, creativity can also inake us feel envy or fear, prompting us to attack people such as Galileo for disputing the

183. See, e.g., Jerome Frank, Mr. Justice Holmes and Non-Euclidean Legal Thinking, 17 CORNELL L.Q. 568, $568 \mathrm{n.2}$ (1932) ("There is, of course, no such thing as 'pure' observation of phenomena, 'pure' description of 'facts.' A 'fact' is a synthesis. An observation or description is selective or interpretative.").

184. See, e.g., Richard Posner, What Has Pragmatism to Offer Law?, 63 S. CAL. L. ReV. 1653, 1656 (1990) (offering a critique of pragmatism, but explaining "the pragmatists' stabs at defining truth - truth is what is fated to be beheved in the long run (Peirce), truth is what is good to believe (James), or truth is what survives im the competition among ideas (Holmes)"'); Margaret Jane Radin, The Pragmatist and the Feminist, 63 S. CAL. L. REv. 1699, 1707 (1990) (suggesting that pragmatism and feminism share "the commitment to finding knowledge in the particulars of experience").

185. See, e.g., Pierre Schlag, Normative and Nowhere to Go, 43 STAN. L. REv. 167, 173 (1990) ("Postmodernism questions the integrity, the coherence, and the actual identity of the humanist mdividual self - the knowing sort of self produced by Enlightenment epistemology and featured so often as the domimant self-inuage of the professional academic.").

186. See, e.g., Joseph W. Singer, The Player and the Cards: Nihilism and Legal Theory, 94 YALE L.J. 1, 4 (1984) ("As a theory of knowledge, nihilism claims that it is impossible to say anything true about the world" because "[a]nything anyone says is as likely to be wrong as it is to be right ....").

187. See, e.g., Mark Kelman, A Guide to Critical Legal Studies 269-70 (1987) (criticizing reification insofar as it limits our thoughts to certain categories).

188. For an example of a sterile judicial dissection of a complex and impressive creation of the human mind, see Lotus Dev. Corp. v. Paperback Software Int'l, 740 F. Supp. 37 (D. Mass. 1990) (spending some fifteen pages on a description of a computer spreadsheet program in terms of binary language, source code and object code, look and feel, user interface, and so forth, to the almost complete exclusion of any reference to the human beings who created it and who use it). 
word of $\operatorname{God}^{189}$ or James Joyce for saying the unspeakable. ${ }^{190}$

We should not turn hastily to the law, expecting it to be inore consistent or inore wise than we are. Law has its limits and cannot be relied on to provide a simple solution to every problem. "Theory expresses our values; it does not create or determine them."191 Given that our opimions about plagiarism are contradictory-sometimes we find it difficult to forgive, at other tinnes we find it difficult to condemn; sometimes we react with embarrassinent, at other times with inalicious pleasure; soinetnnes we despise plagiarists, at other times we empathize with the pressures that led to their actions; sometimes we greet accusations of plagiarism with credence, at other times with suspicion-we should not try to obhiterate these human contradictions by turning to legal reasoming's illusion of predictability. Hegel found "no precise principle of determination available" to decide "to what extent . . . repetition of another's material in one's book [is] a plagiarism" and concluded that the question "cannot be finally settled either in principle or by positive legislation. Hence plagiarisin would liave to be a matter of honour and lield in check by honour."192

A suitable foruin for dealing with plagiarisin may thus he outside the legal system. After all, plagiarisin is just one of the creative risks that people take, and the means of reducing these risks are not to be found in law. Through the very act of creation we risk the inevitable innperfections that intervene between thought and articulation. ${ }^{193}$ Through sharing our creations with others we risk being misquoted or misunderstood. ${ }^{194}$ Through the process of publishing our creations in order to make thein accessible to others we risk yielding to alteration that

189. Cf. Giorgio de Santillana, The Crime of Galileo (1955).

190. Cf. United States v. One Book Called "Ulysses," 5 F. Supp. 182 (S.D.N.Y. 1933) (book not obscene), aff'd, 72 F.2d 705 (2d Cir. 1934).

191. Singer, supra note 186 , at 60 . He continues:

Theory is useful to the extent that it articulates what we value. Since our values conflict, legal theories express our competing values. We "draw a line" between competing principles and then create a theory to describe where we chose to place the line. But the theory does not itself reconcile those values or tell us where to draw the line. It cannot because it is soinething we made up to express those values and the "line" between them.

Id. (footnotes omitted).

192. Hegel's Philosophy of Right If 69, at 56 (T.M. Knox trans., 1952). Two investigators have risen to Hegel's challenge by developing a computer program that searches for identical thirtyletter strings measuring the similarity between two texts in units called "millifreemans." Richard Stone, Court Test for Plagiarism Detector?, 254 SCIENCE 1448 (1991).

193. Cf., e.g., Friedrich Nietzsche, Beyond Good aNd Evil If 296 (Walter Kaufmann trans., Vintage Books 1989) (1886) ("We immortalize what cannot live and fly inuch longer-only weary and mellow things!").

194. E.g., Donald Palmer, Looking at Philosophy 269-70 (1988) (in his familiar but often misunderstood "opiate of the masses" statement about religion, Karl Marx was referring to the drug's medicinal, not sedative, powers). 
leaves us feeling that our work is no longer our own. ${ }^{195}$

When faced with creative risks, creators have the option of either accepting thein or avoiding them. Some authors find the continued risks of creativity to be intolerable and withdraw from participation in the creative contract, declining to publish their works and thereby impoverishing themselves and all of us. ${ }^{196}$ Others feel able to be more generous in sharing their creations; Simone Weil wrote to a friend who had read her notebooks,

You tell me that in my notebooks you have found, besides things which you yourself had thought, others you had not thought but for which you were waiting; so now they belong to you, and I hope that after having been transmuted within you they will one day come out im one of your works. ${ }^{197}$

Aided by our understanding of copyright law, we can seek alternative ways to deal with the problem of plagiarism. Creators can seek help from one another, individually or collectively. Some professional groups, such as the Authors Guild or the National Writers Union, are active in support of authors' rights and in devising accessible procedures through which writers can resolve their grievances. ${ }^{198}$ Academic groups, such as the American Historical Association, maintain sanctioning procedures. ${ }^{199}$ The pressure of public opinion may also be brought to bear against offenders, even in the absence of any possibility of sanction, when people who become aware of plagiarism refuse to keep silent. ${ }^{200}$

Aided by our understanding of plagiarisn1, we can continue to work toward a nore just law of creativity. The law is itself a product of the human creative process-shaped by centuries of tradition, renewed by the infusion of the new and the rediscovery of the old, continually rethought, reanalyzed, and reconstructed, as powerful and noving as any other work of literature. We can nold it to our needs, neither nuaking valid actions too difficult to sustain nor encouraging excessive literary litigiousness. In so doing, we slould not look to faulty nietaphors to resolve our disputes. We must not rely on catcliphrases like "intellectual property" to smiplify a problem-instead, we should try to see the prob-

195. Cf., e.g., A. SCOTT Berg, MAX Perkins: Editor of Genius 297-336 (1978) (events leading to the breach between Thoinas Wolfe and his long-time editor over Wolfe's conviction that editorial changes had been forced upon hin).

196. J.D. Salinger "has not had anything published since 1965 " and has no plans to do so but continues "to write regularly for his own pleasure." Edwin McDowell, Publishing: Visit with J.D. Salinger, N.Y. Times, Sept. 11, 1981, at C24. See generally John Rounano, Salinger Was Playing Our Song, N.Y. Times, June 3, 1979, $\$ 7$ (Book Review), at 11.

197. SimONe WeIL, GRAvity AND GRACE xiii (Emma Craufurd trans., ARK Paperbacks 1987) (1947).

198. See EnCyClopedia of Associations 1144, 2302 (Deborah M. Burek ed., 1992).

199. See Bowen, supra note 25, at 59.

200. The American Historical Association declined in at least one instance to sanction an offender who had already received substantial bad publicity. Id. 
lem in its complexity and trust ourselves to reach a just solution. ${ }^{201}$ As we try to facilitate and encourage the creative process, whether through the law or outside it, we must contmually work to accommodate both process and result, both creator and audience, both property and contract, both ownership and commumication, both simphicity and complexity, both flexibility and consistency, both metaphor and reality, and both creativity and the law.

201. William James, according to Radin, characterized those who "have the temperamental wherewithal to live with incompleteness, openness, uncertainty, skepticism, and the nonideal" as "tough-minded." Radin, supra note 184, at 1714. 



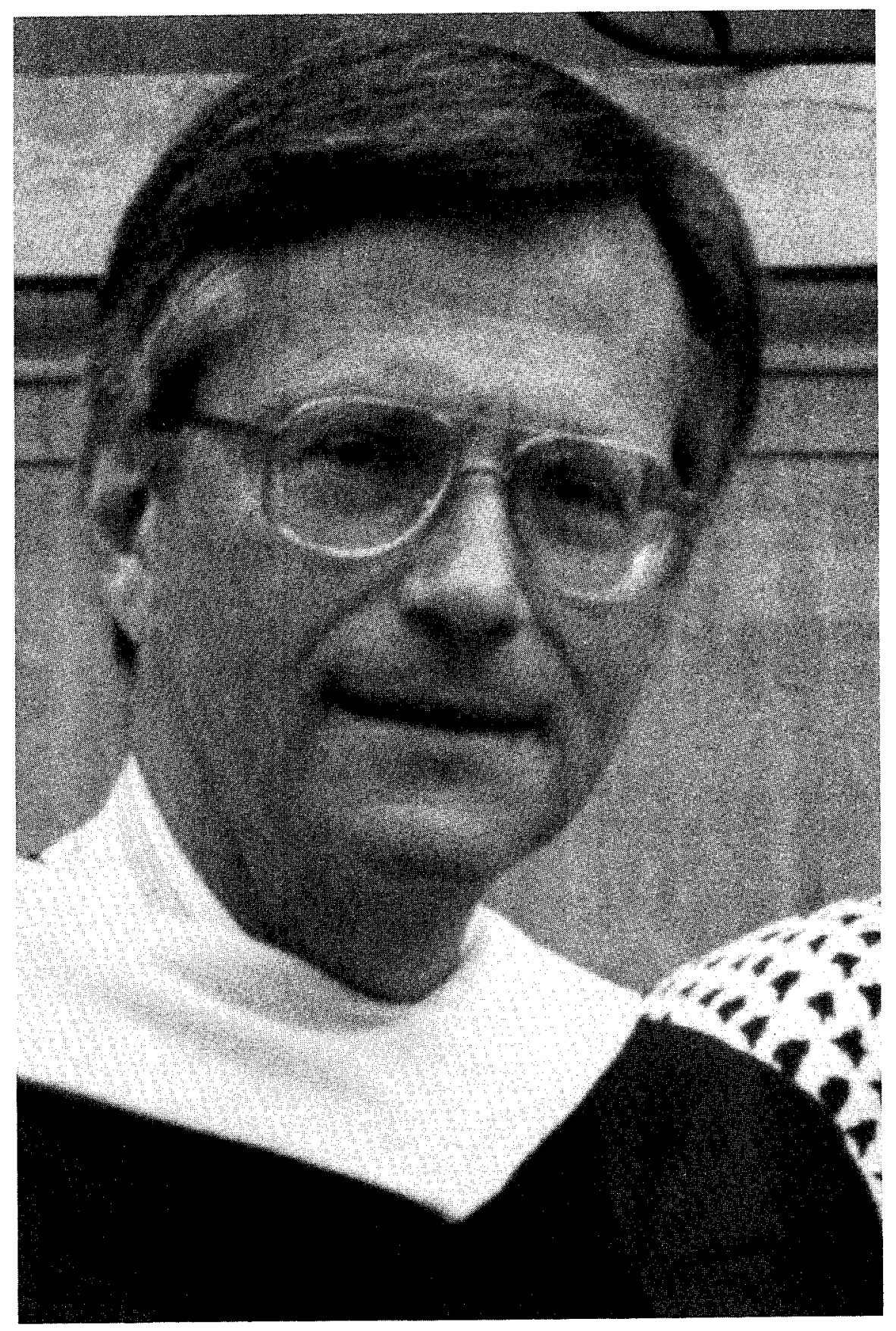

JESSE H. ChOPER 
